\title{
A Swelling-Activated Chloride Current in Microglial Cells is Suppressed by Epac and Facilitated by PKA - Impact on Phagocytosis
}

\author{
Michael Kittla,b Martin Jakabb Tanja S. Steininger ${ }^{a} \quad$ Markus Ritter ${ }^{b, c, d}$ \\ Hubert H. Kerschbaum ${ }^{a}$ \\ aDepartment of Biosciences, University of Salzburg, Salzburg, Austria, 'Institute of Physiology and \\ Pathophysiology, Paracelsus Medical University, Salzburg, Austria, 'Ludwig Boltzmann Institute \\ for Arthritis and Rehabilitation, Paracelsus Medical University, Salzburg, Austria, ${ }^{\mathrm{d}}$ Gastein Research \\ Institute, Paracelsus Medical University, Salzburg, Austria
}

\section{Key Words}

Microglia $\cdot$ BV-2 cells $\cdot$ Phagocytosis $\cdot$ Noradrenaline $\cdot$ Adrenoceptors $\cdot$ Cell volume regulation $\cdot \mathrm{VRAC} \cdot \mathrm{I}_{\text {Cl,swell }} \cdot \mathrm{cAMP} \cdot \mathrm{Epac} \cdot \mathrm{PKA}$

\begin{abstract}
Background/Aims: Volume-regulated anion channels (VRACs) are of particular importance in regulating the cell volume $(\mathrm{CV})$ and give rise to the swelling-activated $\mathrm{Cl}^{-}$current $\left(\mathrm{I}_{\mathrm{Clswell}}\right)$, a main component driving global regulatory volume decrease (RVD) during cell swelling. Because $\mathrm{I}_{C, \text { swell }}$ affects numerous CV-regulated processes like migration, we assume that its role is also indispensable for phagocytosis which requires local cell swelling. Noradrenaline (NA) modulates phagocytosis in macrophages and microglial cells, macrophage-related cells in the central nervous system. Therefore we evaluated whether NA modulates $I_{\text {Clswell }}$ and phagocytosis in microglia. Methods: Experiments were performed in murine microglial BV-2 and primary mouse microglial cells. Patch clamp experiments were performed in BV-2 cells using the amphotericin-perforated method to minimize cytosolic disturbances. Phagocytosis was quantified by scanning electron microscopy. Results: Following activation of $\mathrm{I}_{\text {clswell }}$ by a hypotonic bath solution, noradrenaline, as well as the $\beta$-adrenergic agonist isoproterenol, evoked a transient decrease of $\mathrm{I}_{C \text { l,swell }}$. Repeated application of adrenergic agonists caused a decline of this electrical response. Application of the agonist of exchange protein directly activated by cAMP (Epac), 8-pCPT-2-O-Me-cAMP, or the protein kinase A inhibitor H89 caused a persistent suppression of $\mathrm{I}_{\text {Cl,swell }}$. When isoproterenol was added concomitantly with the hypotonic saline, $I_{\text {CIswell }}$ developed more rapidly compared to control conditions. Uptake of IgG-coated beads was suppressed by NA or H89 when quantified after 15 min of exposure.
\end{abstract}

H. H. Kerschbaum and M. Ritter contributed equally to this work. 


\section{Cellular Physiology Cell Physiol Biochem 2019;52:951-969

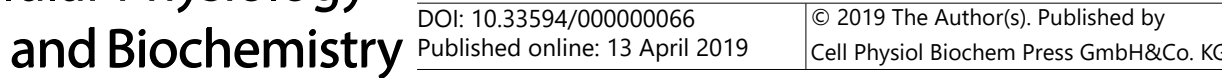 \\ Kittl et al.: Modulation of Microglial I I, swell $/$ VRAC by Noradrenaline via Epac}

Conclusion: The activation of $\beta$-adrenergic receptors in microglial cells triggers a cAMP-Epacdependent and a cAMP-PKA-dependent cascade which affects phagocytosis via modulation of the swelling-activated $\mathrm{Cl}^{-}$current $\mathrm{I}_{\mathrm{Cl} \text { swell }}$.

(C) 2019 The Author(s). Published by Cell Physiol Biochem Press GmbH\&Co. KG

\section{Introduction}

Noradrenaline (NA) modulates phagocytosis in microglial cells, resident macrophages in the central nervous system, as well as in macrophages in the peripheral tissue [1-5]. Interestingly, specific immune responses - e.g. activation and proliferation of macrophages and lymphocytes or release of cytokines - depend on the activation of distinct ion channels [6, 7] [for review see [8-11]]. In line with these observations, recent studies demonstrated that phagocytosis in microglial cells is related to the activation of a swelling-activated $\mathrm{Cl}^{-}$current, $\mathrm{I}_{C l, \text { swell }}[12,13]$ and the $\mathrm{Na}^{+}$-dependent neutral amino acid transporter SNAT1, which mediates cell swelling upon substrate transport [14]. Whether $\mathrm{I}_{C l, s w e l l}$ in microglia is modulated by adrenergic agonists is unknown.

Global regulatory cell volume decrease (RVD), which follows cell swelling, depends on activation of $\mathrm{K}^{+}$- and $\mathrm{Cl}^{-}$channels, whereas global cell volume regulatory volume increase (RVI), which follows cell shrinkage, requires $\mathrm{Na}^{+}$-influx pathways [15] [for review see [1620]]. Local subcellular volume regulatory processes contribute to lamellipodium formation in migrating cells [21-27] and engulfment pseudopodium formation in phagocytes [13]. In microglial cells, replacement of $\mathrm{Na}^{+}$by other cations or application of the $\mathrm{Na}^{+}$channel blocker tetrodotoxin attenuates phagocytosis [14] [for review see [28]]. In addition, $\mathrm{Cl}^{-}$channel blockers impair phagocytosis in microglial cells $[12,13]$. We suggest that in phagocytes like microglial cells, a $\mathrm{Na}^{+}$-influx promotes local swelling leading to the formation of a phagocytic cup at the contact area between the phagocyte and the particle, and that $\mathrm{Cl}^{-}$efflux prevents thickening of the pseudopodia to keep the membrane expansion locally $[13,14]$. Thus, while at the tip of the crest of the engulfment pseudopodia a local influx of osmolytes and water promotes swelling, in its proximity an efflux of osmolytes and water causes shrinkage to constrain the local swelling [13]. Following local volume increase, the newly formed pouch is subsequently colonized by cytoskeletal elements to stabilize the engulfment pseudopodia. A similar line of arguments has been used for the interpretation of lamellipodia formation and cell migration [21-27].

NA triggers cAMP-dependent signaling cascades [29-31]. The ubiquitous second messenger cAMP shows differences in its subcellular compartmentalization, time course and downstream signaling cascades, which could lead to diverse and even opposite physiological responses to the same agonist in immune cells. For example, an initial and transient cAMP elevation is required for T cell activation, whereas a sustained elevation of cAMP suppresses $T$ cell activation [8]. The G protein-cAMP-dependent signaling cascade shows an early molecular dichotomy at the level of the cAMP-binding proteins, protein kinase A (PKA) and the exchange protein directly activated by cAMP (Epac). Because PKA and Epac are coupled to distinct signaling cascades, the dichotomy at the level of these effector proteins may also have consequences in the physiological response to cAMP elevating-agents. While the PKA signaling cascades include numerous phosphorylation steps, the Epac signaling cascades include small GTPases, phospholipases, as well as mitogen- and lipid-activated kinases [for review see [30-32]]. In myeloid cells, cAMP-dependent pathways have been reported to increases or decreases phagocytosis [3-5, 33-36]. In murine microglial cells, both application of the Epac-agonist 8-pCPT-2-O-Me-cAMP and suppression of PKA activity impair phagocytosis, indicating that the Epac-Rap pathway suppresses and the PKA-dependent phosphorylation enhances phagocytosis [5, 36]. Extracellular modulators, like NA, activate cAMP-dependent pathways [29]. In microglia noradrenergic agonists either increase or decrease phagocytosis $[3,5]$. Among the ion channels, whose activities are modulated by PKA- as well as Epac-dependent processes are $\mathrm{Cl}^{-}$channels. In microglial cells, PKA activates a $\mathrm{Cl}^{-}$conductance [37]. In rat hepatocytes, the Epac agonist 8-pCPT-2-0-Me-cAMP activates a 


\section{Cellular Physiology Cell Physiol Biochem 2019;52:951-969

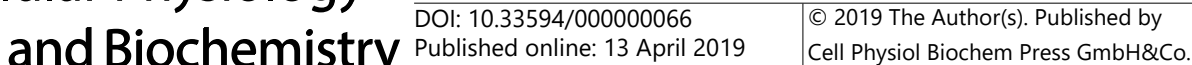 \\ Kittl et al.: Modulation of Microglial I ${ }_{\mathrm{Cl}, \text { wwell }} /$ VRAC by Noradrenaline via Epac}

$\mathrm{Cl}^{-}$current, which has similar properties as the swelling-activated $\mathrm{Cl}^{-}$current [38]. Although a cAMP-PKA-dependent pathway activates a $\mathrm{Cl}^{-}$conductance in microglial cells [37], we found that a cAMP/Epac-dependent pathways suppresses phagocytosis [5]. Thus, the Epacdependent suppression of phagocytosis resembles impairment of phagocytosis following blockade of $\mathrm{Cl}^{-}$channels in microglial cells [13].

In the present study we performed patch-clamp recordings and quantification of phagocytosis to estimate the association between cAMP-dependent modulation of the swelling-activated $\mathrm{Cl}^{-}$current $\mathrm{I}_{C l \text { swell }}$ with cAMP-dependent phagocytosis. Our perforated patchclamp recordings revealed that both the Epac agonist 8-pCPT-2-0-Me-cAMP and the PKAantagonist $\mathrm{H} 89$ suppressed $\mathrm{I}_{C l, \text { swell, }}$, which indicates that PKA-dependent mechanisms increase $\mathrm{I}_{C I \text { swell }}$ Further, NA and the $\beta$-adrenergic agonist isoproterenol (ISOP) transiently suppressed osmotically-activated $\mathrm{I}_{C l \text { swell }}$. Compared to hypotonic solution alone, its simultaneous application with ISOP leads, however, to faster activation kinetics of the current, as indicated by a left-shift of the $T_{50}$ value (i.e. time to half-maximal current activation), hence indicating on the long term rather an activation than inhibition of $\mathrm{I}_{C l, \text { swell }}$

\section{Materials and Methods}

\section{Chemicals and solutions}

Unless stated otherwise, all chemicals were obtained from Sigma-Aldrich. The stock solution of (1) DL-norepinephrine hydrochloride $(50 \mathrm{mg} / \mathrm{mL})$ was prepared in ultrapure water, stored at $-20^{\circ} \mathrm{C}$; $(2)$ ( \pm )-propranolol hydrochloride $\left(12 \mathrm{mg} / 4 \mathrm{~mL}\right.$ ) in dimethylsulfoxide (DMSO), stored at $4^{\circ} \mathrm{C}$; (3) phentolamine hydrochloride $\left(12 \mathrm{mg} / 4 \mathrm{~mL}\right.$ ) in ultrapure water, stored at $-20^{\circ} \mathrm{C}$; (4) $\mathrm{N}$-[2-(p-Bromocinnamylamino)ethyl]5 -isoquinolinesulfonamide dihydrochloride (H89) $(5 \mathrm{mg} / \mathrm{mL})$ in sterile ultrapure water, stored at $4^{\circ} \mathrm{C}$; (5) yohimbine hydrochloride $(10 \mathrm{mg} / 4 \mathrm{~mL})$ in ultrapure water, stored at $-20^{\circ} \mathrm{C}$; $(6)$ metaraminol $(+)$-bitartrate salt $(200 \mathrm{mg} / 4 \mathrm{~mL})$ in ultrapure water, stored at $-20^{\circ} \mathrm{C}$; (7) (R)-(-)-phenylephrine hydrochloride $(20 \mathrm{mg} /$ $\mathrm{mL}$ ) in ultrapure water, stored at $4^{\circ} \mathrm{C}$; (8) DCPIP (4-[(2-Butyl-6,7-dichloro-2-cyclopentyl-2, 3-dihydro-1-oxo$1 \mathrm{H}$-inden-5-yl)oxy] butanoic acid) in ethanol, stored at $-20^{\circ} \mathrm{C}$. The stock solutions were diluted in serum-free DMEM or Ringer solution to appropriate concentrations for respective cell treatment. Working solutions were prepared immediately prior to their application.

\section{Cell culture}

Primary microglial cells were isolated from forebrains of 1-5 day-old wild-type C57 black 6J mice as previously described [17, 26, 39]. Animals were handled according to federal law. In brief, mice were decapitated followed by mechanical dissociation of cerebral cortices through centrifugation. Afterwards, the cell suspension was filtered using a $70 \mu \mathrm{m}$ cell strainer (BD Biosciences) and cultivated in $0.1 \%$ polyD-lysine (PDL)-coated $75 \mathrm{~cm}^{2}$ culture flasks in Dulbecco's Modified Eagle's Medium (DMEM) containing 4.5 $\mathrm{g} / \mathrm{L}$ glucose, L-glutamine and sodium pyruvate (PAA Laboratories) supplemented with 10\% (v/v) FCS and $1 \%\left(\mathrm{v} / \mathrm{v}\right.$ ) penicillin/streptomycin (Gibco) at $37^{\circ} \mathrm{C}$ in a humidified atmosphere and $5 \% \mathrm{CO}_{2}$. After $10-14$ days in co-cultivation with adherent astrocytes, microglial cells were harvested via shaking from the astrocyte monolayer [40] for $3 \mathrm{~h}$. The supernatant, containing >97\% primary microglia was used for experiments.

Microglial BV-2 cells, generated by infecting primary mouse microglia with a v-raf/v-myconcogencarrying-retrovirus (J2) [41], were grown and maintained in $25 \mathrm{~cm}^{2}$ culture flasks in DMEM supplemented with $2.2 \mathrm{~g} / \mathrm{L}$ glucose and $10 \%\left(\mathrm{v} / \mathrm{v}\right.$ ) fetal calf serum (FCS; Biochrom) at $37^{\circ} \mathrm{C}$ in a humidified atmosphere and $5 \% \mathrm{CO}_{2}$ and sub-cultured once a week. For experiments, BV-2 cells as well as primary microglial cells were seeded into Petri dishes on PDL-coated glass coverslips (diameter $12 \mathrm{~mm}$ ) at a density of $8 \times 10^{4}$ cells/ $\mathrm{ml}$ and allowed to adhere overnight for up to $18 \mathrm{~h}$. Following two washing steps, cells were left untreated or treated with the respective solvents (control) or with reagents as indicated. 


\section{Cellular Physiology Cell Physiol Biochem 2019;52:951-969

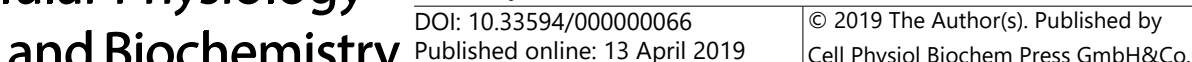 \\ Kittl et al.: Modulation of Microglial $\mathrm{I}_{\mathrm{Cl}, \text { wwell }} /$ VRAC by Noradrenaline via Epac}

\section{Determination of phagocytosis by scanning electron microscopy}

In each engulfment experiment, cells were cultured in $2 \mathrm{~mL}$ serum-free DMEM for $45 \mathrm{~min}$. Cells were pretreated with NA, ISOP, phenylephrine, metaraminol, phentolamine, propranolol for $5 \mathrm{~min}$, with 8-pCPT2-O-Me-cAMP for $15 \mathrm{~min}$ and with $\mathrm{H} 89$ for $30 \mathrm{~min}$. Then, cells were exposed to $4 \mu \mathrm{m}$ IgG-coated hydrophobic microspheres (Invitrogen) in the absence or presence of adrenergic agonists, antagonists, 8-pCPT-2-0-MecAMP, or $\mathrm{H} 89$ for $15 \mathrm{~min}$.

For Scanning electron microscopy cells were fixed after the respective treatments in $2.5 \%(\mathrm{v} / \mathrm{v})$ glutaraldehyde (Agar Scientific Limited) in phosphate buffered saline (PBS; pH 7.2-7.4) for $1 \mathrm{~h}$, rinsed four times with PBS for $1 \mathrm{~h}$ and subsequently dehydrated in a graded series of ethanol $(50,70,80,90$, $96,100 \% \mathrm{v} / \mathrm{v}$ ). Thereafter, cells were air-dried for two times using hexamethyldisilazane (HMDS) (Fluka/ Sigma-Aldrich). Coverslips were attached on pins and 12 times for 15 seconds sputter-coated with a 50 nm layer of gold using an Agar Sputter Coater. Samples were visualized with a Cambridge Stereoscan 250 scanning electron microscope (Cambridge Instruments). For evaluation of the engulfment experiments only the numbers of completely engulfed microspheres were used.

\section{Electrophysiology}

BV-2 cells were plated on $0.01 \%$ PDL-coated glass coverslips (diameter $12 \mathrm{~mm}$ ) and cultured for at least $24 \mathrm{~h}$ in DMEM. Coverslips were transferred to an RC-25 recording chamber and mounted on a Nikon Eclipse inverted microscope. All experiments were performed at room temperature and were recorded in the whole-cell (ruptured or perforated) patch clamp mode. Ruptured whole-cell mode was achieved by applying a slight suction through the pipette whereas the perforated whole-cell configuration was achieved by adding $130 \mu \mathrm{M}$ amphotericin B to the pipette solution. Recordings were started as soon as the serial resistance was below $30 \mathrm{M} \Omega$ for the perforated and below $10 \mathrm{M} \Omega$ for the ruptured configuration. Patch electrode resistances were 3-7 M $\Omega$. After establishing the whole-cell configuration the cells were superfused with an isotonic extracellular solution and data were recorded using an EPC-10 amplifier controlled by PatchMaster software (HEKA). Cell membrane potential $\left(\mathrm{V}_{\text {mem }}\right)$ recordings were performed in the zerocurrent clamp mode and whole-cell currents were monitored using $500 \mathrm{~ms}$ voltage ramps from $-100 \mathrm{mV}$ to $+100 \mathrm{mV}$. Ramps were elicited every 10 seconds and the holding potential between the ramps was kept at $-70 \mathrm{mV}$. For $\mathrm{V}_{\mathrm{mem}}$ and whole-cell recordings the same intra- and extracellular solutions were used. The intracellular (pipette) solution contained (in mM): $70 \mathrm{~K}_{2} \mathrm{SO}_{4}, 10 \mathrm{NaCl}, 10 \mathrm{KCl}, 4 \mathrm{MgCl}_{2}, 2 \mathrm{CaCl}_{2}, 5 \mathrm{HEPES}$ free acid, 5 EGTA (249 mOsm/kg, pH 7.2 adjusted with $\mathrm{KOH}$ ). The extracellular solution contained (in mM): 140 $\mathrm{NaCl}, 5.6 \mathrm{KCl}, 2.5 \mathrm{CaCl}_{2}, 1.5 \mathrm{MgCl}_{2}, 10$ HEPES free acid, 4.5 D-glucose, 5 mannitol $(300 \mathrm{mOsm} / \mathrm{kg}$, pH 7.4 adjusted with $\mathrm{NaOH}$ ). Whole-cell $\mathrm{Cl}^{-}$currents were elicited using the same ramp protocol with a holding potential kept at $0 \mathrm{mV}$ to avoid any voltage-activated currents. The intracellular solution for the $\mathrm{Cl}^{-}$current recordings contained (in mM): $100 \mathrm{CsCl}, 5 \mathrm{MgCl}_{2}, 10 \mathrm{HEPES}$ free acid, 11 EGTA, $65 \mathrm{D}-(+)-$ raffinose, $2 \mathrm{MgATP}$ (306 mOsm/kg, pH 7.2 adjusted with $\mathrm{CsOH}$ ). The isosmotic extracellular solution contained (in $\mathrm{mM}$ ): 100 $\mathrm{NaCl}, 2.5 \mathrm{CaCl}_{2}, 2.5 \mathrm{MgCl}_{2}, 10$ HEPES free acid, 95 mannitol (302 mOsm/kg, pH 7.2 adjusted with $\mathrm{NaOH}$ ). Swelling-activated $\mathrm{Cl}^{-}$currents $\left(\mathrm{I}_{C l, \text { swell }}\right)$ were elicited by superfusion with a $70 \%$ hypoosmotic extracellular solution $(210 \mathrm{mOsm} / \mathrm{kg})$ obtained by omission of mannitol. Reagents like NA, ISOP, H89 and 8-pCPT-2O-Me-cAMP were applied with a hyposmotic extracellular solution after reaching steady-state $\mathrm{I}_{C l \text { swell }}$ Bath solution exchange was performed with a valve-controlled gravity-driven perfusion system (ALA Scientific Instruments) at a flow rate of 3-5 $\mathrm{mL} / \mathrm{min}$. Osmolalities of intra- and extracellular solutions were measured using a vapor pressure osmometer (Wescor). The relative anion permeabilities were calculated as described elsewhere [42].

\section{Statistical analysis}

All data are presented as mean \pm SEM (standard error of the means). Statistical analyses were performed using Prism 7 (GraphPad Software). Patch clamp data were analyzed with Fit-Master software (HEKA) and Igor Pro 6 (Wave Metrics). Exponential and sigmoidal fits were done using Igor Pro 6 and Prism 7, respectively. In phagocytosis-experiments, 200-300 cells were counted in randomly selected microscopic fields. Each experiment was repeated at least three times. Ordinary or repeated measures one-way ANOVA (Tukey's post-hoc test), paired or unpaired double-sided t-tests were used as applicable to test the levels of significance. Results were regarded as statistically significant at $\mathrm{p}<0.05$. Graphs were created with GraphPad Prism 7 and Igor Pro 6. 


\section{Cellular Physiology Cell Physiol Biochem 2019;52:951-969

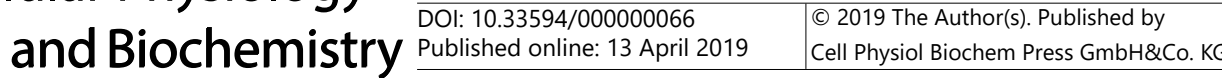 \\ Kittl et al.: Modulation of Microglial I I, swell $/$ VRAC by Noradrenaline via Epac}

\section{Results}

Noradrenaline triggers a variety of intracellular signaling cascades [29], which could be extenuated or even eliminated during whole-cell recordings when the cell is dialyzed with the pipette solution. Therefore, to minimize disturbances of intracellular signaling cascades during single-cell recordings, we monitored the membrane potential $\left(\mathrm{V}_{\text {mem }}\right)$ as well as ion currents during application of adrenergic agonists using the amphotericin B perforated patch-clamp technique.

\section{Characteristics of $I_{\text {Clswell }}$}

Replacement of the isotonic by the hypotonic saline $(210 \mathrm{mOsm} / \mathrm{kg})$ induced a slowly developing outwardly rectifying current, $\mathrm{I}_{C l, \text { swell }}$. Fig. 1 visualizes $\mathrm{Cl}^{-}$currents evoked either by voltage ramps or by voltage steps from $-100 \mathrm{mV}$ to $+100 \mathrm{mV}$. The holding potential was kept at $0 \mathrm{mV}$ to inactivate voltage-dependent $\mathrm{K}^{+}$-channels. We observed in the perforated patch recordings an outwardly rectifying current with a reversal potential at $0 \mathrm{mV}$ and slight inactivation at strong positive potentials. To control extra- as well as intracellular ionic composition, we performed ruptured patch clamp experiments to evaluate the permeability of the $\mathrm{I}_{C l, s w e l l}$. Equimolar substitution of $\mathrm{Cl}^{-}$with $\mathrm{I}^{-}$and gluconate- increased and decreased the relative permeability, respectively $\left(P_{\mathrm{I}} / P_{\mathrm{Cl}}=1.48 \pm 0.08, \mathrm{n}=5 ; P_{\text {gluc }} / P_{\mathrm{Cl}}=0.19 \pm 0.02, \mathrm{n}=4\right)$. We also observed that the current was completely suppressed by the $\mathrm{Cl}^{-}$channel blocker DCPIB $(10 \mu \mathrm{M} ; \mathrm{n}=3$; figure 1). In summary, the current is sensitive to (1) osmotic gradients, (2) substitution of $\mathrm{Cl}^{-}$with $\mathrm{I}^{-}$or gluc', (3) the $\mathrm{Cl}^{-}$channel blocker DCPIB and (4) displays slight inactivation at strong positive potentials. Therefore this current fulfills major criteria of a swelling-activated $\mathrm{Cl}^{-}$current, $\mathrm{I}_{C l \text { swell }}[13,15,18,26,43]$.

Noradrenaline (NA) and isoproterenol (ISOP) transiently suppress $I_{\text {Cl,swell }}$ in microglial cells Under isotonic conditions neither NA $(1 \mu \mathrm{M})$ nor ISOP $(1 \mu \mathrm{M})$ changed $\mathrm{V}_{\text {mem }}$ or the basal ion currents, $\mathrm{I}_{\text {cl,basal }}$ (data not shown; NA: $\mathrm{V}_{\text {mem }} \mathrm{n}=5$, $\mathrm{I}_{\text {cl,basal }} \mathrm{n}=2$; ISOP: $\mathrm{V}_{\text {mem }} \mathrm{n}=4, \mathrm{I}_{\text {cl,basal }} \mathrm{n}=10$ ). In further experiments, cells were exposed to hypotonic conditions and NA was added when $\mathrm{I}_{C l, \text { swell }}$ had reached a plateau. As shown in figure 2, application of the $\alpha$ - and $\beta$-adrenergic agonist, NA, induced a profound transient decrease of $\mathrm{I}_{C l, \text { swell }}$ by about $23 \%$. Six out of 18 cells $(33 \%)$ did not respond to $1 \mu \mathrm{M}$ NA and were not included in the statistics (figures $2 \mathrm{~A}$, $B, C)$. The suppression of the current was dependent on the NA concentration (figure $2 \mathrm{D}$ ). Similarly, the $\beta$-adrenergic agonist ISOP transiently reduced $\mathrm{I}_{C l, s w e l l}$ (figure $3 \mathrm{~A}, \mathrm{~B}, \mathrm{C}$ ). During continued hypotonic conditions the cells were refractory to the same stimulus. As shown in figures 2 and 3, removal of and repeated exposure to NA or ISOP during hypotonic conditions resulted in a reduction of the response size; i.e. compared to the first application response, the second one was either absent or diminished. Four out of four (100\%) NA-exposed cells and seven out of eight ISOP-exposed cells (87\%) did not reveal a detectable decrease of $\mathrm{I}_{C l \text { swell }}$ during a second application of NA and ISOP. This indicates a sustained action of the adrenergic agonists on $\mathrm{I}_{C l, \text { swell }}$. However, establishing isotonic conditions for a few minutes and re-addition of hypotonic saline re-established the responsiveness of the cells to the same adrenergic agonists, NA and ISOP, leading to a comparable transient reduction of $\mathrm{I}_{c l, s w e l l}$ . The time courses of the $\mathrm{I}_{C l, \text { swell }}$ decrease- and recovery following application of NA or ISOP were similar. The time constants $\tau$ of the current decrease and recovery were $1.09 \pm 0.20$ $\min$ and $3.56 \pm 0.76 \mathrm{~min}(\mathrm{n}=4)$ for NA and $0.87 \pm 0.12 \mathrm{~min}$ and $3.06 \pm 0.51 \mathrm{~min}(\mathrm{n}=5)$ for ISOP, respectively. These findings could indicate that $\beta$-adrenergic receptors are functionally connected to temporally segregated mutually inhibiting signaling pathways. Depending on the dominance of one of the signaling pathways, the ion current either increases or decreases. Two candidates of such a dichotomy are PKA and Epac. 


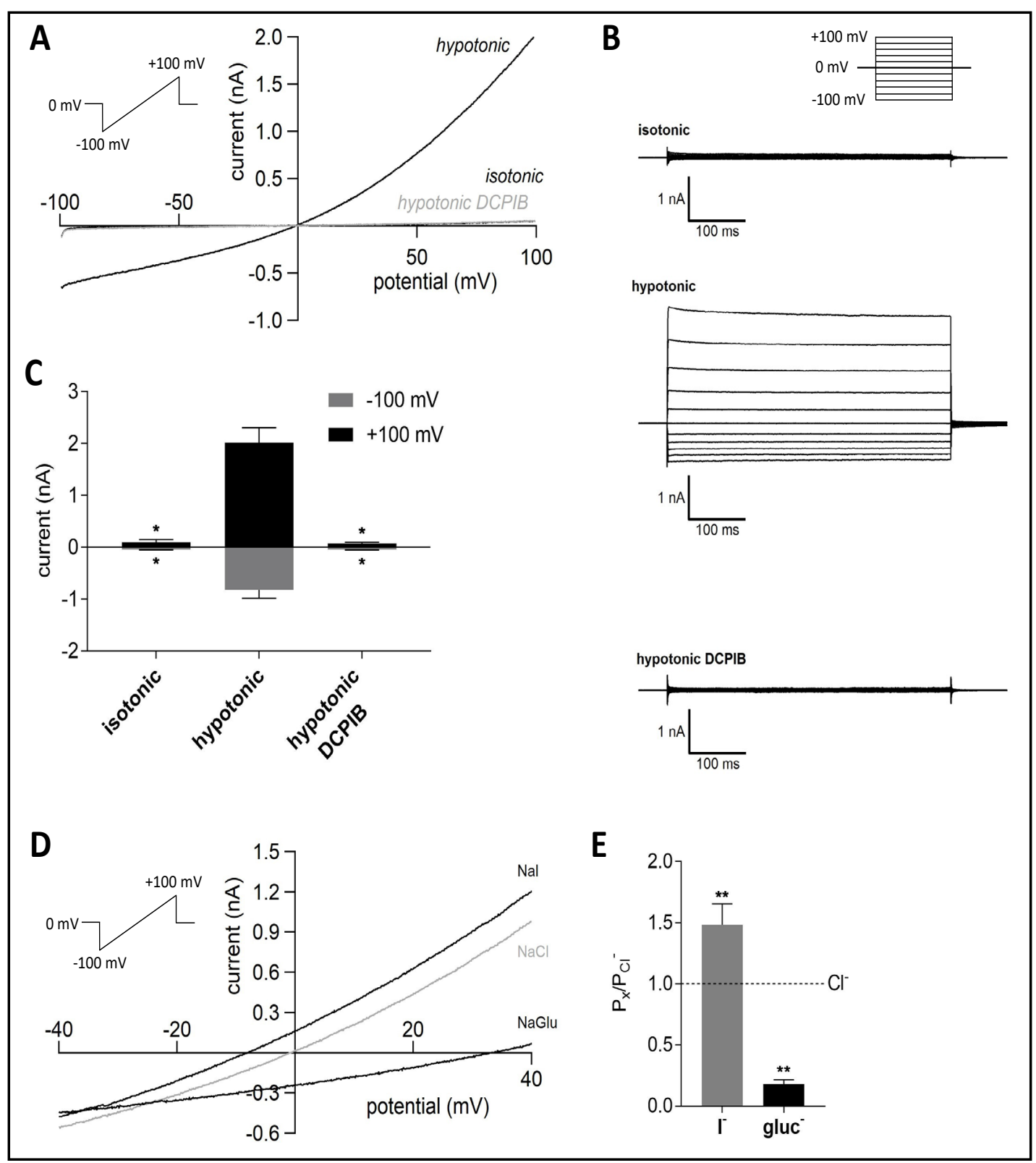

Fig. 1. Swelling activated $\mathrm{Cl}^{-}$currents $\left(\mathrm{I}_{\mathrm{Cl}, \text { swell }}\right)$ in BV-2 microglial cells. (A) Representative current-voltage relationship obtained by $500 \mathrm{~ms}$ voltage ramps under isotonic and hypotonic conditions in the absence and presence of the $\mathrm{Cl}^{-}$channel blocker DCPIB $(10 \mu \mathrm{M})$. Note that the voltage ramp tracings under isotonicand hypotonic/DCPIB conditions are superimposed. (B) Representative current traces elicited by 500 $\mathrm{ms}$ voltage-steps during the superfusion with isotonic- (upper trace) and hypotonic bath solution in the absence (middle trace) and presence (lower trace) of $10 \mu \mathrm{M}$ DCPIP. (C) Mean peak currents under isotonicand hypotonic conditions in the absence and presence of $10 \mu \mathrm{M}$ DCPIB $(n=3$; asterisks indicate significant differences to hypotonic). (D) Determination of reversal potentials using ruptured whole-cell patch clamp under symmetric intra- and extracellular $\mathrm{Cl}^{-}$concentrations and upon equimolar extracellular substitution of $\mathrm{NaCl}\left(\mathrm{Cl}^{-}\right)$with $\mathrm{NaI}\left(\mathrm{I}^{-}\right)$and Na-gluconate (gluc'). The anion replacements lead to shifts of the reversal potential to negative- $\left(\mathrm{I}^{-}\right)$and positive (gluc') values, respectively. Overlay of three representative original tracings. (E) Relative anion permeability $\left(\mathrm{P}_{\mathrm{x}} / \mathrm{P}_{\mathrm{Cl}}{ }^{-}\right)$for $\mathrm{I}^{-}$and gluc ions with respect to $\mathrm{Cl}^{-}$as calculated from the shift of the respective reversal potentials as shown in D. Asterisks indicate significant differences to the anion permeability for $\mathrm{Cl}^{-}(\mathrm{n}=3-4)$. Means \pm SEM; ${ }^{*} \mathrm{p}<0.05$, ** $\mathrm{p}<0.01$. 


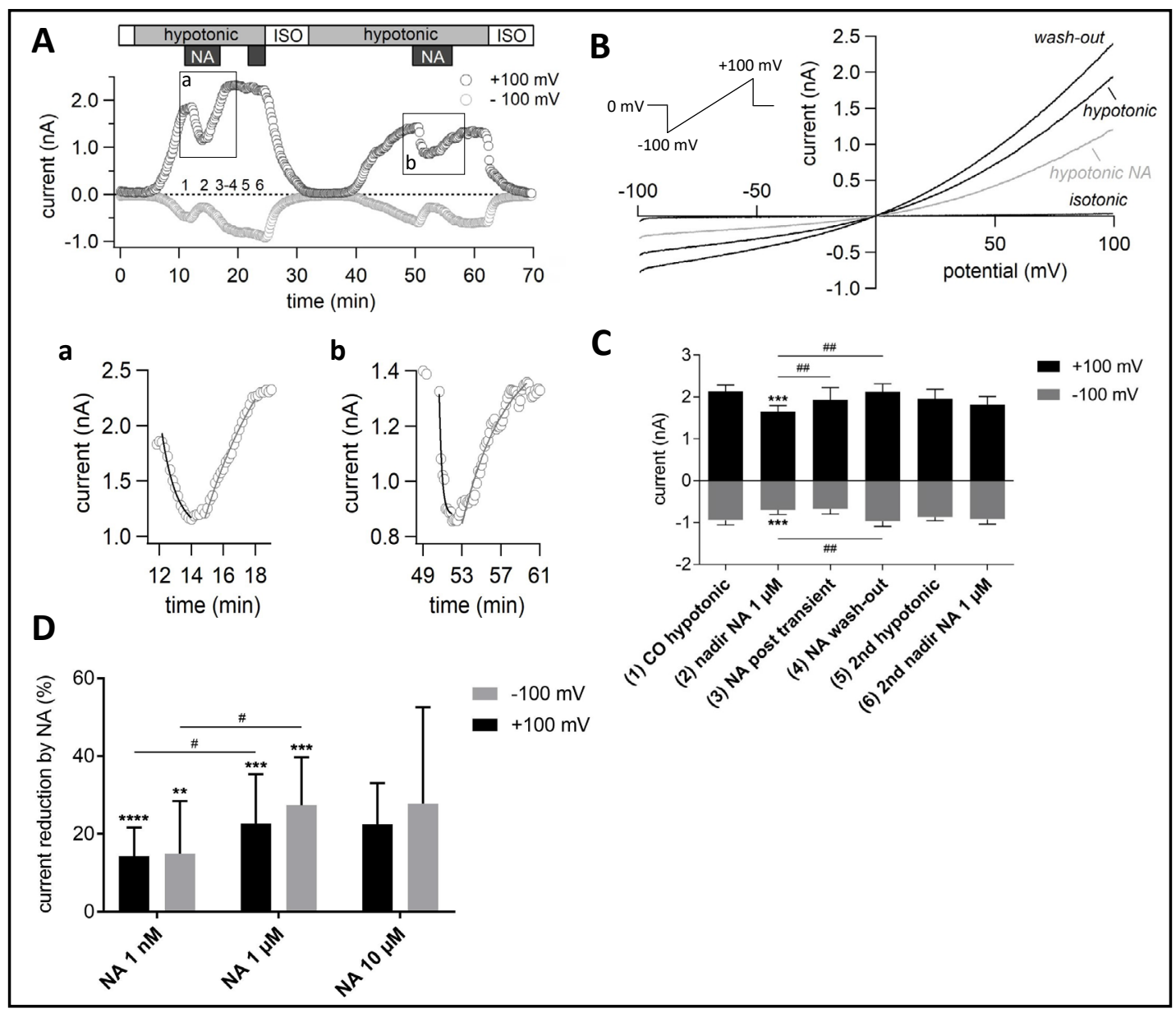

Fig. 2. Transient inhibition and desensitization of $I_{\text {Cl,swell }}$ in response to noradrenaline (NA). (A) Time course of $\mathrm{I}_{\mathrm{Cl}, \text { swell }}$ of a single experiment under isotonic (ISO) and hypotonic conditions in the absence and presence of $1 \mu \mathrm{M}$ NA. Each circle represents the current obtained every 10 seconds at $-100 \mathrm{mV}$ (lower trace) and $+100 \mathrm{mV}$ (upper trace). Numbers 1-3 indicate time points during the NA-induced transient reduction phase of $\mathrm{I}_{\mathrm{Cl}, \text { swell }}, 4$ after NA wash out and 5-6 during the second NA application. (a) and (b) are close ups of the $\mathrm{I}_{\mathrm{Cl}, \mathrm{swell}}$ time course as indicated by the windows in A. Data were fitted by single exponential functions during $\mathrm{I}_{\mathrm{Cl}, \text { swell }}$ reduction (black line) and recovery (grey line), respectively. (B) Representative currentvoltage relationships $\left(\mathrm{V}_{\text {mem }}\right.$ ramps from $-100 \mathrm{mV}$ to $+100 \mathrm{mV}$ ) recorded under isotonic conditions, hypotonic conditions in the absence and presence of NA and after wash out of NA. (C) Mean amplitudes of $\mathrm{I}_{\mathrm{Cl} \text {,swell }}$ under hypotonic conditions in the absence and presence of NA as shown in panel A $(n=3-12)$. Numbers $1-6$ in brackets refer to the time points of analyses for every condition as indicated by the same numbers in panel A. (D) Relative inhibition of $\mathrm{I}_{\mathrm{Cl}, \text { swell }}$ at $+100 \mathrm{mV}$ (black bars) and $-100 \mathrm{mV}$ (grey bars) by $1 \mathrm{nM}, 1 \mu \mathrm{M}$ and $10 \mu \mathrm{M}$ NA (n=3-12). Asterisks indicate significant differences to control (CO). Hashes denote significant differences as indicated. Means $\pm S E M ;^{*} \mathrm{p}<0.05,{ }^{* *} \mathrm{p}<0.01,{ }^{* * *} \mathrm{p}<0.001,{ }^{* * * *} \mathrm{p}<0.0001 ; \# \mathrm{p}<0.05, \# \# \mathrm{p}<0.01$.

\section{Isoproterenol (ISOP) evokes a rapid $I_{C l, s w e l l}$ development when co-applied with a hypotonic solution}

In the above experiments, we added the adrenergic agonists after the development of $\mathrm{I}_{C l, \text { swell }}$. Because $\mathrm{I}_{C l, \text { swell }}$ (1) showed a transient decrease following application of adrenergic agonists and (2) was larger compared to pre-application conditions following wash-out at least in some ISOP experiments, the long-lasting effect of adrenergic agonists could be an increase in $\mathrm{I}_{C l, \text { swell }}$ Therefore, we exposed cells to hypotonic solution simultaneously with 1 $\mu \mathrm{M}$ ISOP. As shown in figure 4 , the time courses of activation of $\mathrm{I}_{C l, s w e l l}$ differed between cells 


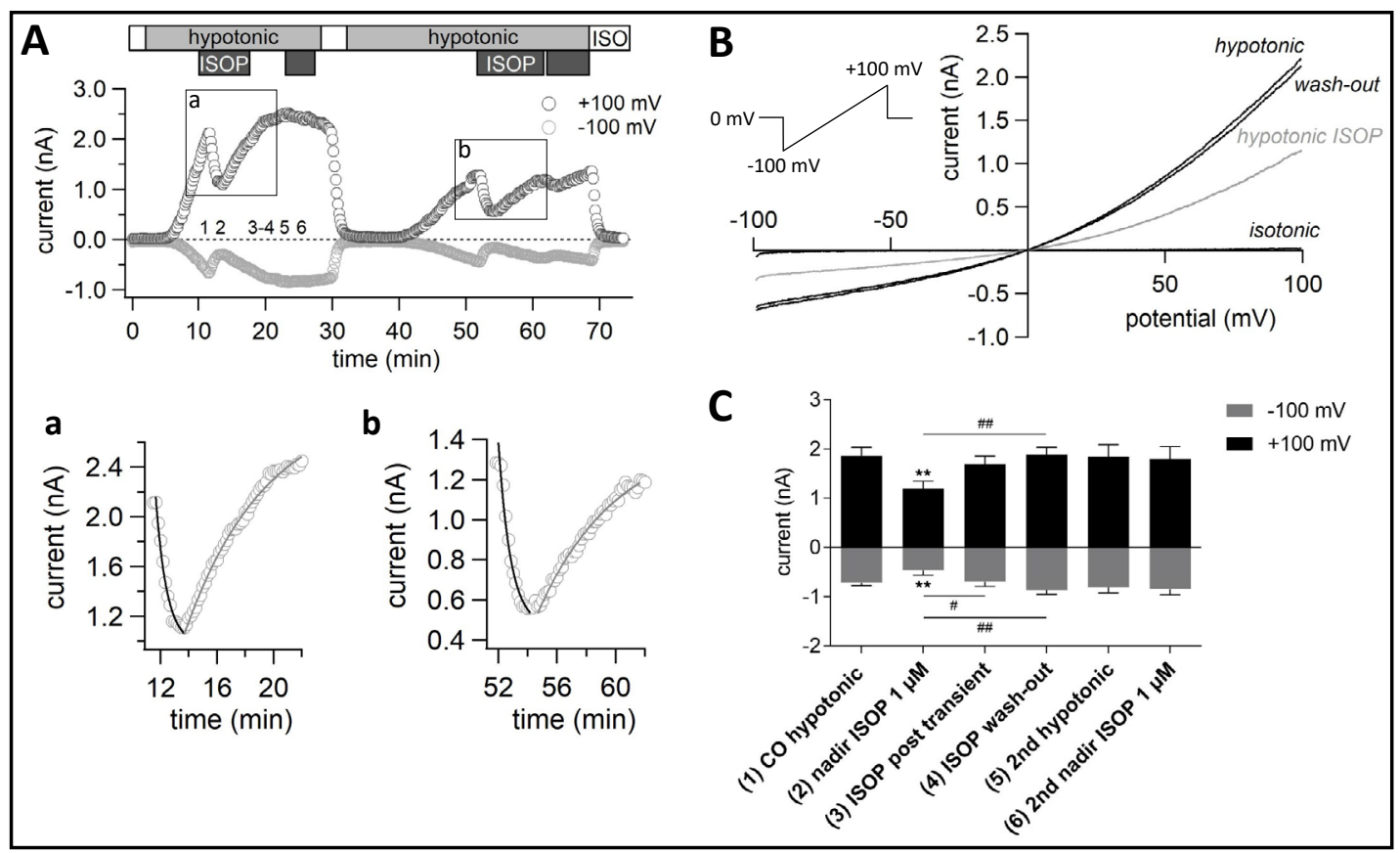

Fig. 3. Transient inhibition and desensitization of $\mathrm{I}_{\mathrm{Cl} \text { swell }}$ in response to isoproterenol (ISOP). (A) Time course of $\mathrm{I}_{\mathrm{Cl}, \text { swell }}$ of a representative experiment under isotonic (ISO) and hypotonic conditions in the absence and presence of $1 \mu \mathrm{M}$ ISOP. Each circle represents the current obtained every 10 seconds at $-100 \mathrm{mV}$ (lower trace) and $+100 \mathrm{mV}$ (upper trace). Numbers 1-3 indicate time points during the ISOP-induced transient reduction phase of $\mathrm{I}_{\mathrm{Cl}, \text { swell, }} 4$ after ISOP wash out and 5-6 during the second ISOP application. (a) and (b) are close ups of the $\mathrm{I}_{\mathrm{Cl}, \mathrm{swell}}$ time course as indicated by the windows in A. Data were fitted by single exponential functions during $\mathrm{I}_{\mathrm{Cl}, \text { swell }}$ reduction (black line) and recovery (grey line), respectively. (B) Representative current-voltage relationships $\left(\mathrm{V}_{\text {mem }}\right.$ ramps from $-100 \mathrm{mV}$ to $\left.+100 \mathrm{mV}\right)$ recorded under isotonic and hypotonic conditions in the absence and presence of ISOP and after washout of ISOP. (C) Average amplitudes of $\mathrm{I}_{\mathrm{Cl}, \text { swell }}$ under hypotonic conditions in the absence and presence of $1 \mu \mathrm{M}$ ISOP. Results of 4-6 individual experiments as shown in panel A $(n=4-6)$. The corresponding time points for every condition (1-6) are indicated in panel A. Asterisks indicate significant differences to control (CO). Hashes indicate significant differences as indicated. Means $\pm S E M ;{ }^{* *} \mathrm{p}<0.01 ; \# \mathrm{p}<0.05, \# \# \mathrm{p}<0.01$.

swollen in hypotonic solution in the absence and presence of ISOP. The time to half-maximal current activation $\left(\mathrm{T}_{50}\right)$ significantly shifted to the left from $457.7 \pm 16.7(\mathrm{n}=7)$ to $330.2 \pm 15.1$ seconds $(n=6)$ at $+100 \mathrm{mV}$, and from $504.4 \pm 19.3(\mathrm{n}=7)$ to $371.7 \pm 14.3$ seconds $(\mathrm{n}=6)$ at -100 $\mathrm{mV}$.

The Epac agonist 8-pCPT-2-O-Me-cAMP and the PKA-inhibitor H89 persistently suppress $I_{\text {Clswell }}$

PKA as well as Epac, are potential targets for cAMP, which increases upon $\beta$-adrenergic stimulation. Therefore, we evaluated whether these cAMP-activated proteins affect $\mathrm{I}_{C l, \text { swell }}$. Following the establishment of $\mathrm{I}_{C l, \text { swell }}$ the cells were superfused with the PKA antagonist H89 (figure 5) or the Epac agonist 8-pCPT-2-0-Me-cAMP (figure 6). As shown in figure 5, within a few seconds after $\mathrm{H} 89$ application the outward current of $\mathrm{I}_{\text {Clswell }}$ at $+100 \mathrm{mV}$ decreased by $28 \pm 8 \%$ and the inward current at $-100 \mathrm{mV}$ decreased by $30 \pm 10 \%(\mathrm{n}=10$; two cells did not respond to $\mathrm{H} 89$ and were not included in the statistics). In contrast to NA and ISOP, H89 suppressed $\mathrm{I}_{C l, s w e l l}$ as long as the drug was present. When applied for a second time, the cells did no longer respond to the PKA inhibitor. Fig. 6 shows that $\mathrm{I}_{C l, s w e l l}$ is also sensitive to the Epac agonist 8-pCPT-2-0-Me-cAMP. Its addition to the hypotonic solution led to a permanent reduction of the outward current at $+100 \mathrm{mV}$ by $33 \pm 9 \%$ and the inward current at $-100 \mathrm{mV}$ 


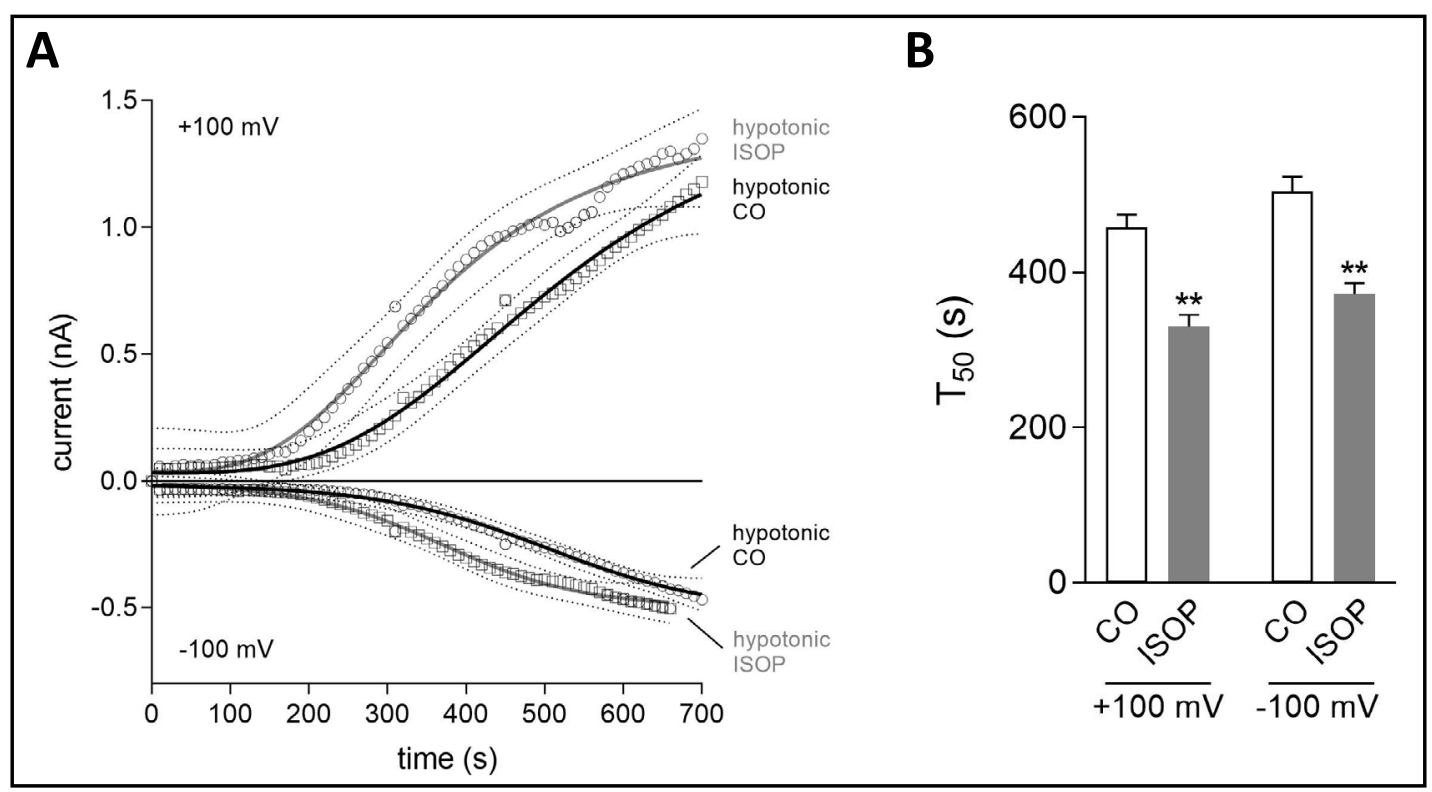

Fig. 4. Activation of $I_{C l, s w e l l}$ in the presence of isoproterenol (ISOP). (A) Time course of $I_{C l, s w e l l}$ activation under hypotonic conditions in the absence (control, CO; $n=7$ ) and presence of $1 \mu \mathrm{M}$ isoproterenol (ISOP; $\mathrm{n}=6$ ). Each circle represents the current obtained every 10 seconds at $-100 \mathrm{mV}$ (inward currents, lower traces) and $+100 \mathrm{mV}$ (outward currents, upper traces). Dotted lines denote 95\% confidence intervals. Data were fitted by a sigmoidal Boltzmann function which was used to calculate the time to reach the half-maximal current activation $\left(\mathrm{T}_{50}\right.$ ). (B) $\mathrm{T}_{50}$ values for outward currents at $+100 \mathrm{mV}$ and inward currents at $-100 \mathrm{mV}$ in the absence (control, $\mathrm{CO}$ ) and presence of $1 \mu \mathrm{M}$ ISOP. Data were determined from individual sigmoidal Boltzmann fits. Means \pm SEM. Asterisks denote significant difference from the respective control value. ${ }^{* *}$ $\mathrm{p}<0.01$.

by $39 \pm 9 \%(n=6$; one cell did not respond to the Epac agonist and was not included in the statistics). Furthermore, $\mathrm{I}_{C l, \text { swell }}$ tended to be larger after wash-out of 8-pCPT-2-0-Me-cAMP at $+100 \mathrm{mV}(140 \pm 26 \% ; n=4)$ and was significantly larger at $-100 \mathrm{mV}(158 \pm 24 \% ; n=4)$. The elevated current was also insensitive to the Epac agonist when it was applied for the second time. Notably, the reversal potential of the outwardly rectifying current did not change when H89 or 8-pCPT-2-0-Me-cAMP was applied, suggesting that these agents do not affect the ion selectivity in addition to the $\mathrm{Cl}^{-}$conductance. Analysis of the time courses of the $\mathrm{I}_{C l, \text { swell }}$ suppression and recovery phases revealed single exponential functions. The time constants $\tau$ for the decreases were $1.32 \pm 0.18 \mathrm{~min}(\mathrm{n}=3)$ and $1.91 \pm 0.64 \mathrm{~min}(\mathrm{n}=3)$ for H89 and 8-pCPT-2O-Me-cAMP, respectively. Recovery from $\mathrm{I}_{\text {Cl,swell }}$ suppression following drug washout revealed a $\tau$ of $4.28 \pm 0.73 \mathrm{~min}(\mathrm{n}=3)$ for H89 and of $4.29 \pm 0.31 \mathrm{~min}(\mathrm{n}=3)$ for 8-pCPT-2-0-Me-cAMP.

\section{Noradrenaline and the PKA inhibitor H89 impair phagocytosis in microglial cells}

According to a proposed model of pseudopodium movement during phagocytosis, which involves $I_{C l, s w e l l}$ to regulate its cell volume [26], and according to our electrophysiological observation that adrenergic agonists modulate $\mathrm{I}_{C l, \text { swell }}$, adrenergic responses on phagocytosis are of interest. Uptake of IgG-coated microspheres by microglial cells at the single cell level was quantified using scanning electron microscopy. Figures 7 and 8 visualize that NA suppresses microsphere uptake in the pM- and $\mathrm{nM}$ range as well as above $1 \mu \mathrm{M}$. Because NA activates $\alpha$ - as well as $\beta$-adrenergic receptors [29], we used $\alpha$-adrenergic antagonists to isolate the contribution of $\beta$-adrenergic receptors to microsphere uptake. Yohimbine, a selective $\alpha 2$-adrenergic antagonist, suppressed microsphere uptake in the presence of $1 \mathrm{pM}$ NA as well as in the presence of $1 \mu \mathrm{M}$ NA. Phentolamine, an $\alpha 1$ - and $\alpha 2$-adrenergic antagonist, decreased microsphere uptake in the presence of $1 \mu \mathrm{M}$ NA, but not in the presence of 1 pM NA (figure 7 D). Surprisingly, metaraminol, an $\alpha 1$ - and $\alpha 2$-adrenergic agonist, as well 
Fig. 5. Reversible persistent inhibition and desensitization of $\mathrm{I}_{\mathrm{Cl} \text { swell }}$ in response to the PKA inhibitor H89. (A) Time course of $\mathrm{I}_{\mathrm{Cl}, \text { swell }}$ of a single experiment under isotonic (ISO), hypotonic and hypotonic conditions in the absence and presence of H89. Each circle represents the current obtained every 10 seconds at $-100 \mathrm{mV}$ (lower trace) and $+100 \mathrm{mV}$ (upper trace). 1, $\mathrm{I}_{\mathrm{Cl}, \text { swell }}$ during hypotonicity; 2, during the application of H89; 3, after H89washout; 4-5, during second application of H89. (B) Representative currentvoltage relationships $\left(\mathrm{V}_{\text {mem }}\right.$ ramps from $-100 \mathrm{mV}$ to $+100 \mathrm{mV}$ ) recorded under isotonic and hypotonic conditions in the absence and presence of H89. (C) Mean amplitudes of $\mathrm{I}_{\mathrm{Cl}, \text { swell }}$ under hypotonic conditions in the absence and presence of $1 \mu \mathrm{M}$ H89 as shown in panel A $(\mathrm{n}=3-8$ for conditions 1-3; conditions 4-5 are the means of two single observations $(n=2)$. The corresponding time points for every condition 1-5 are indicated in panel A. Asterisks indicate significant differences to control (CO); hashes indicate significant differences as indicated. Means \pm SEM; ** $\mathrm{p}<0.01$; \# $\mathrm{p}<0.05$; \# $\mathrm{p}<0.01$.

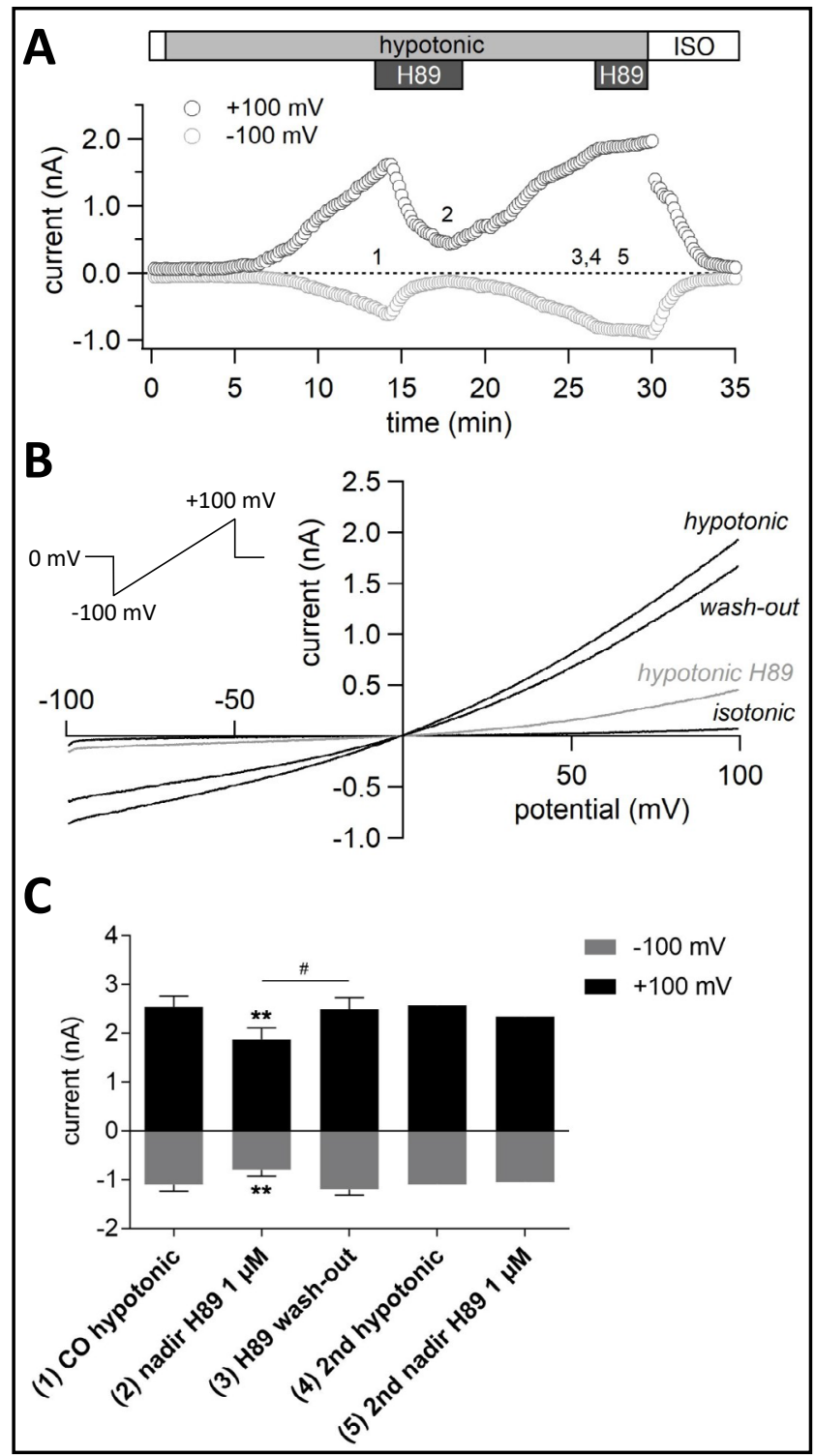

as phenylephrine, an $\alpha 1$-adrenergic agonist, significantly suppressed microsphere uptake (figure 7D). Phenylephrine also suppressed microsphere uptake in primary microglial cells (figure $8 \mathrm{~B}$ ). The $\beta$-adrenergic antagonist propranolol did not affect microsphere uptake in the presence of $1 \mathrm{pM} \mathrm{NA}$, but it decreased it in the presence of $1 \mu \mathrm{M}$ and $10 \mu \mathrm{M}$ NA (figure 7E).

The PKA inhibitor H89, suppressed microsphere uptake in BV-2 cells (figure 7F), indicating that a basal PKA activity facilitates microsphere uptake. Fig. $7 \mathrm{~F}$ visualizes the additive inhibitory effect of NA, phentolamine and H89 on the suppression of microsphere uptake. Surprisingly, we found a similar additive effect of phentolamine and H89 when NA was not applied to the cells. 
Fig. 6. Reversible persistent inhibition and desensitisation of $\mathrm{I}_{\mathrm{Cl}, \text { swell }}$ in response to the Epac- activator 8-pCPT-2-0-Me-cAMP (8pCPT). (A) Time course of $\mathrm{I}_{\mathrm{Cl}, \text { swell }}$ of a single representative experiment under isotonic (ISO) and hypotonic conditions in the absence and presence of 8-pCPT2-0-Me-cAMP and after washout of the drug. Each circle represents the current obtained every 10 seconds at $-100 \mathrm{mV}$ (lower trace) and $+100 \mathrm{mV}$ (upper trace). 1 indicates $\mathrm{I}_{\mathrm{Cl}, \text { swell }}$ during hypotonicity, 2 during the application of 8-pCPT-2-0Me-cAMP, 3 after 8-pCPT-2-0-Me-cAMPwashout, 4-5 during second application of 8-pCPT-2-0-Me-cAMP. (B) Representative current-voltage relationships $\left(\mathrm{V}_{\text {mem }}\right.$ ramps from $-100 \mathrm{mV}$ to $+100 \mathrm{mV}$ ) recorded under isotonic and hypotonic conditions in the presence and absence of 8-pCPT2-0-Me-cAMP. (C) Average amplitudes of $\mathrm{I}_{\mathrm{Cl}, \text { swell }}$ under hypotonic conditions in the presence and absence of $50 \mu \mathrm{M}$ 8-pCPT2-0-Me-cAMP. Results of 3-5 individual experiments as shown in panel A $(n=3-5)$. The corresponding timepoints for every condition (1-5) are indicated in panel A. Asterisks indicate significant differences to control (CO). Hashes indicate significant differences as indicated. Means \pm SEM; * $\mathrm{p}<0.05 ; \# \mathrm{p}<0.05$, \# $\mathrm{p}<0.01$.
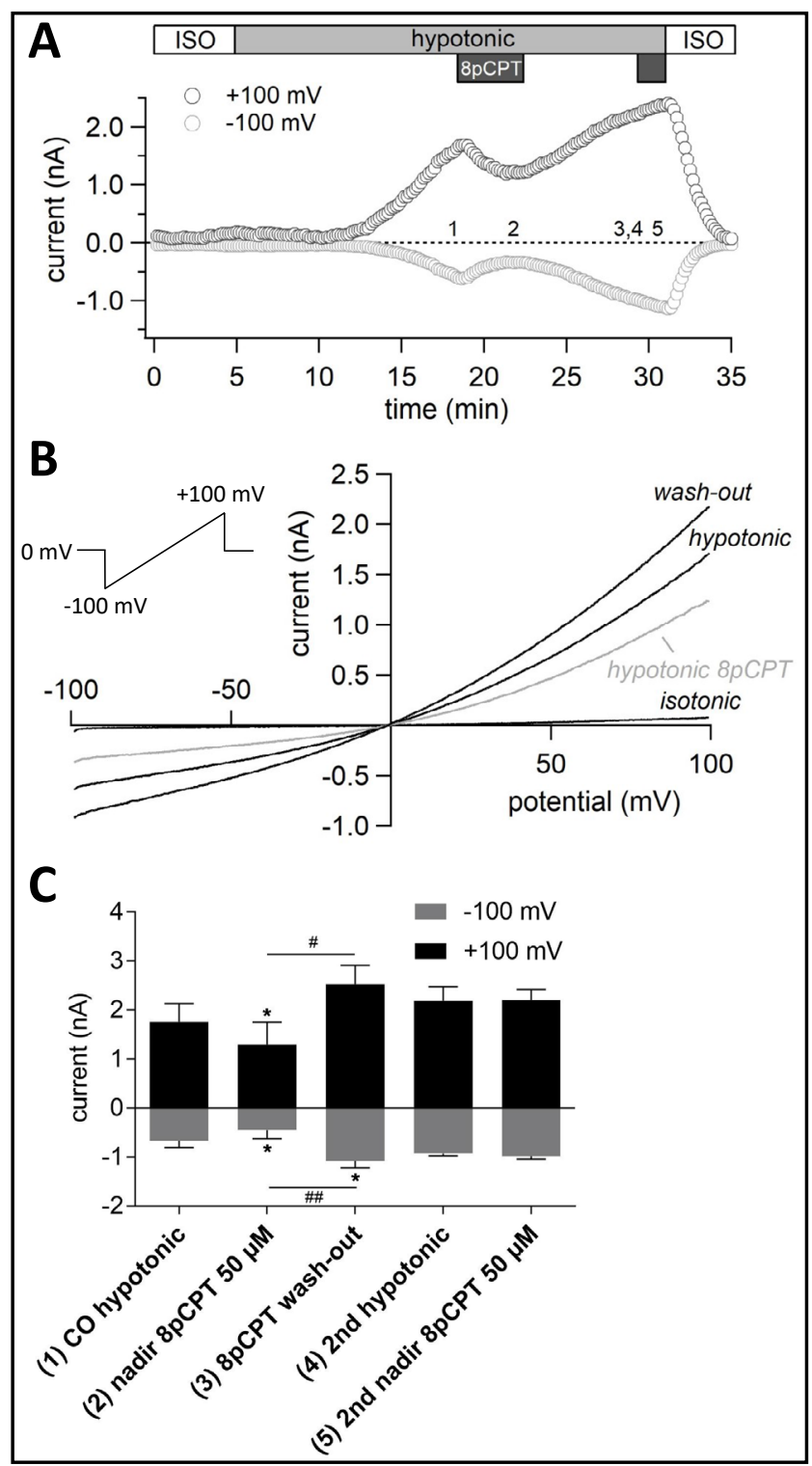

\section{Discussion}

Our findings suggest that NA modulates $\mathrm{I}_{\text {Clswell }}$ through two distinct cAMP-dependent pathways. First, adrenergic agonists suppress $I_{\text {Cl,swell }}$ by a cAMP-Epac-dependent pathway. Second, adrenergic agonists enhance $\mathrm{I}_{C l, s w e l l}$ by a cAMP-PKA-dependent pathway. According to our phagocytosis experiments, we suggest an adrenergic-cAMP-Epac-dependent pathway in an early phase, evidenced by a decrease in particle uptake as shown earlier [5]. In a later phase of phagocytosis, we assume an adrenergic-cAMP-PKA-dependent pathway.

\section{Modulation of $I_{C l, \text { swell }}$ by cAMP-dependent processes}

$\mathrm{I}_{C l, \text { swell }}$ is an ubiquitous anion current in immune cells. Its classical signatures are activation by cell swelling and dependence on intracellular ATP. ATP is required for activation and maintenance of $I_{C I \text { swell }}[15,44,45]$. Whether ATP or one of its metabolites directly or indirectly affects $\mathrm{I}_{C l \text { swwell }}$ is unknown. Presumably, G-proteins are not involved in $\mathrm{I}_{C l, \text { swell }}$ activation in microglial cells, because intracellular dialysis of these cells with the non-hydrolysable G-protein activating nucleotide GTP $\gamma S$ had no significant effect on $\mathrm{I}_{C l, s w e l l}$ 
Fig. 7. Noradrenergic suppression of IgGcoated microspheres uptake is mediated by $\alpha$ - and $\beta$-adrenergic receptors. Scanning electron microscopic evaluation

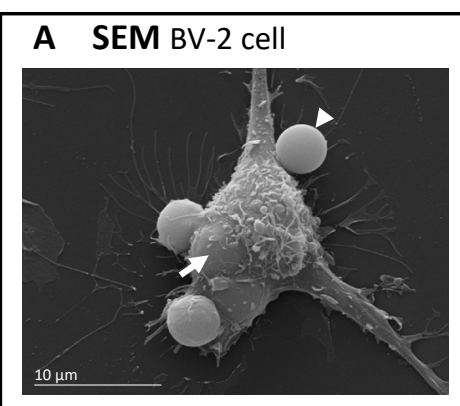

B $\quad$ BV-2 cells; $15 \mathrm{~min}$

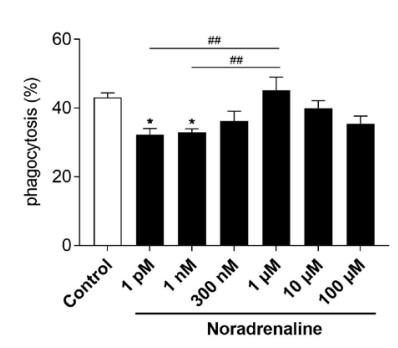
that application of $\alpha$ - or $\beta$-adrenergic antagonists or agonists as well as suppression of PKA with H89 modulates microsphere uptake. In most experiments, cells were exposed to the drugs for $15 \mathrm{~min}$. In the experiments shown in panel C, cells were exposed to NA for $60 \mathrm{~min}$. Microsphere uptake is normalized to the total number of cells analyzed. Data are shown as means \pm SEM.

(A)

Representative BV-2 cell showing attached (one example is shown with an

E BV-2 cells; $15 \mathrm{~min}$

D BV-2 cells; $15 \mathrm{~min}$
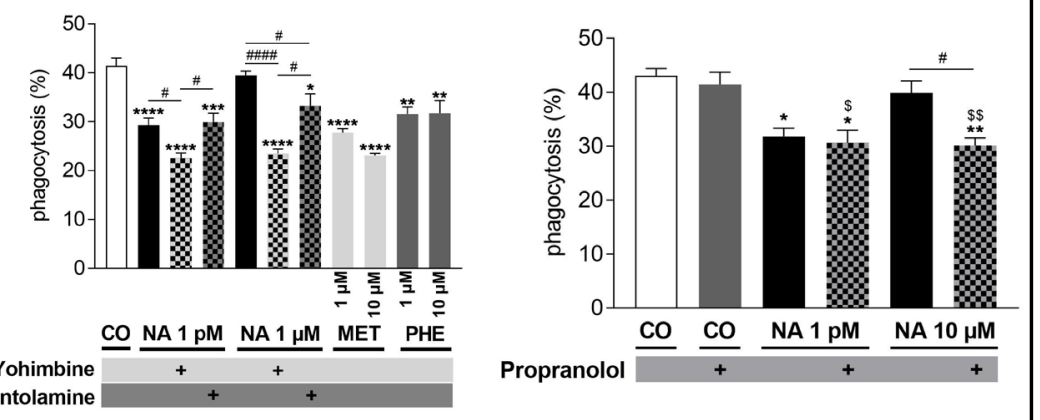

F BV-2 cells; $15 \mathrm{~min}$

arrowhead) as well as engulfed (one example is shown with an arrow) microspheres. (B) Microsphereuptake across different NA concentrations. One-way ANOVA revealed a significant suppressive effect between control and $1 \mathrm{pM}$ or $1 \mathrm{nM} \mathrm{NA}$. (C) Bath application of NA for $60 \mathrm{~min}$ did not reveal a significant difference between NA and control. (D) Co-application of NA and yohimbine ( $\alpha 2$ - adrenergic antagonist) or NA and phentolamine ( $\alpha 1$ - and $\alpha 2$-adrenergic antagonist) as well as application of metaraminol ( $\alpha 1$ and $\alpha 2$-adrenergic agonist) and phenylephrine ( $\alpha 1$-adrenergic agonist) in the absence (control, CO) and presence of adrenergic agonists (noradrenaline, NA; metaraminol, MET; phenylephrine, PHE) and/or antagonists (Yohimbine, Phentolamine). One-way ANOVA revealed significant differences between control and most treatment conditions (*). Pairwise comparison revealed significant differences between $1 \mathrm{pM}$ NA and co-application of NA and yohimbine, $1 \mu \mathrm{M} \mathrm{NA}$ and co-application of NA and yohimbine, as well as $1 \mu \mathrm{M}$ NA and co-application of NA and phentolamine (\#). (E) Co-application of NA and propranolol ( $\beta$-adrenergic antagonist). One-way ANOVA revealed significant differences if compared to control $\left({ }^{*}\right)$ or propranolol treatment (\#). Pairwise t-test showed a significant difference between $10 \mu \mathrm{M} \mathrm{NA}$ and co-application of NA and propranolol. Comparison of NA $(1 \mathrm{pM}$ or $10 \mu \mathrm{M})$ alone and NA in the presence of propranolol is indicated by \$. (F) Co-application of H89 (PKA antagonist) and phentolamine. One-way ANOVA revealed significant differences when compared to control $\left({ }^{*}\right)$ or H89 treatment (\#). Means $\pm S E M ;{ }^{*} p<0.05,{ }^{* *} p<0.01$, ${ }^{* * *} \mathrm{p}<0.001,{ }^{* * * *} \mathrm{p}<0.0001$ denote significant difference when compared to control [white bar]; $\# \mathrm{p}<0.05$, \#\# $\mathrm{p}<0.01$, \#\#\# $\mathrm{p}<0.001$ denote significant difference when compared to phentolamine [PHE; dark grey bar]); $\$ p<0.05, \$ p<<0.01$, denote significant difference when compared to $1 \mu \mathrm{M} N \mathrm{~N}$ alone. 


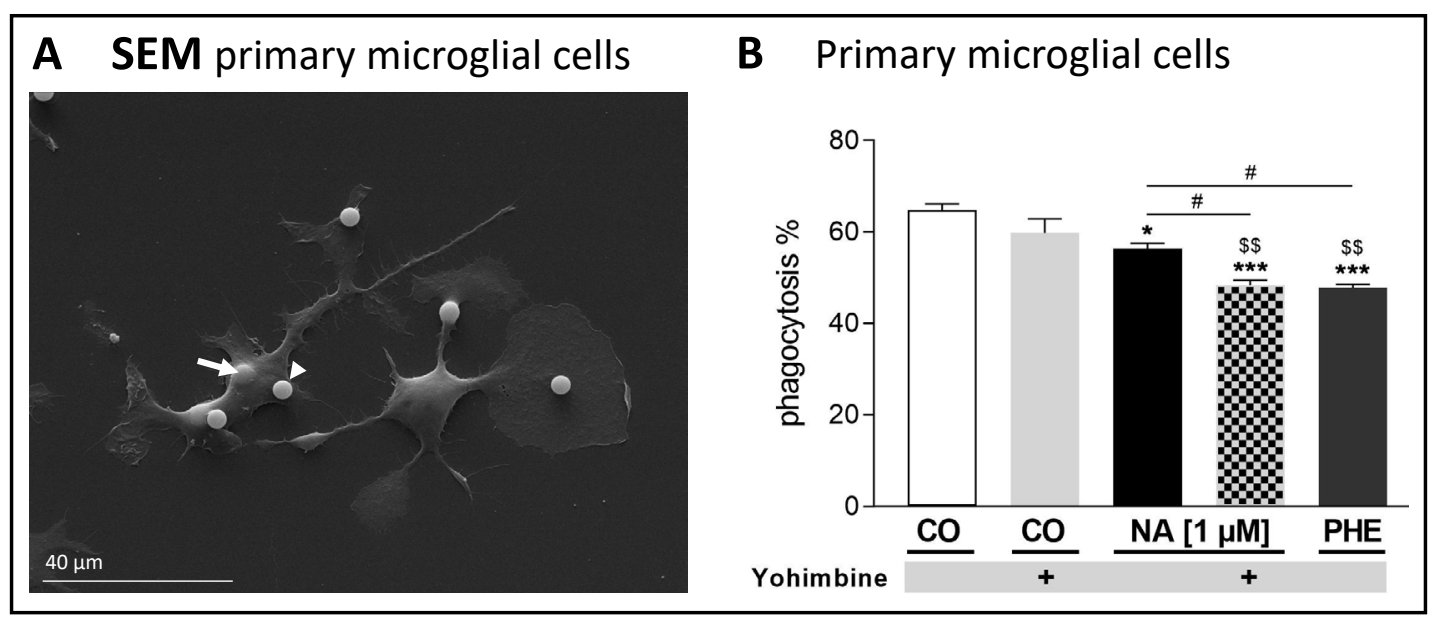

Fig. 8. Noradrenergic suppression of IgG-coated microspheres uptake in primary microglial cells. (A) Representative image of primary microglial cells showing attached (one example is shown with an arrowhead) as well as engulfed (one example is shown with an arrow) microspheres. (B) Average effect on microsphere uptake in the absence (CO) [white bar] and presence of (1) the $\alpha$ - and $\beta$-adrenergic agonist noradrenaline (NA $1 \mu \mathrm{M}$ ) [black bar], (2) the $\alpha 2$-adrenergic antagonist, yohimbine $(10 \mu \mathrm{M})$ [grey bar], (3) NA $(1 \mu \mathrm{M})$ in addition yohimbine $(10 \mu \mathrm{M})$ [hatched bar] and (4) the $\alpha 1$-adrenergic agonist, phenylephrine (PHE $10 \mu \mathrm{M}$ ) [dark grey bar]. Primary microglial cells were exposed to IgG-coated microspheres for $15 \mathrm{~min}(\mathrm{n}=3)$. Asterisks denote significant differences when compared to control [white bar] and dollar signs \$ denote denote significant differences when compared to $\mathrm{CO}+$ yohimbine [grey bar]. Hashes indicate significant differences as indicated. Mean $\pm S E M ;{ }^{*} \mathrm{p}<0.05,{ }^{* *} \mathrm{p}<0.01,{ }^{* * *} \mathrm{p}<0.001 ; \$ \$ \mathrm{p}<0.01 ; \# \mathrm{p}<0.05$.

activation in hypo-osmotic conditions [44]. However, swelling of S49 mouse lymphoma cells in hypotonic medium increases adenylate cyclase activity in a G-protein-independent pathway [46]. Further, $\mathrm{Ca}^{2+}$ - and bicarbonate ions regulate the soluble adenylyl cyclase [for review sees [31]]. Because VRAC channels, which give rise to $\mathrm{I}_{C l, \text { swell }}$ are also permeable to bicarbonate [47], a mutual interaction between soluble adenylyl cyclase and ion channels is conceivable. However, a few studies even demonstrate that a cAMP-PKA-dependent pathway activates a $\mathrm{Cl}^{-}$current in immune cells, which shows similar properties to an osmoticallyactivated $\mathrm{I}_{C l \text { swell }}$ but is activated under isotonic conditions $[37,48]$. Dialysis of BV-2 cells with cAMP or with the catalytic subunit of PKA in the pipette solution activates an outwardly rectifying $\mathrm{Cl}^{-}$current in isotonic conditions [37]. Both, the cAMP-dependent- as well as the PKA-dependent $\mathrm{Cl}^{-}$current are sensitive to the $\mathrm{Cl}^{-}$channel blockers NPPB and flufenamic acid [37]. A similar cAMP-dependent modulation of a $\mathrm{Cl}^{-}$current has been shown in hepatocytes, where a glucagon-cAMP-Epac-dependent pathway activates a $\mathrm{Cl}^{-}$current resembling $\mathrm{I}_{\text {Clswell }}$ [49]. Thus, in addition to the classical hallmarks of $\mathrm{I}_{C l, s w e l l}$, the present and a previous study suggest that $I_{C l, s w e l l}$ is modulated by cAMP-dependent pathways [37]. Moreover, it has recently been shown, that $I_{C l, \text { swell }}$ of human atrial myocytes is augmented by NA, an effect mimicked by the Epac agonist 8-pCPT-2-0-Me-cAMP and inhibited by an Epac antagonist, thus implying that the effect of NA is mediated by an Epac-dependent pathway in these cells [50]. This contrasts the finding of our present study showing an inhibition of $\mathrm{I}_{\text {Cl,swell }}$ by NA and 8-pCPT2-0-Me-cAMP. The reason(s) for this discrepancy is (are) currently unclear but may be due to cell type- and/or species-specific differences, and eventually also due to the technical approach (ruptured vs. perforated whole-cell recordings).

Noradrenergic agonists elevate cAMP in microglial cells [5]. In general, a $\beta$-adrenoceptor$\mathrm{G}_{\mathrm{s}}$-adenylyl cyclase-dependent increase in cAMP activates the cAMP-binding proteins PKA and Epac [for review see $[29,31,32,51]$. These proteins accumulate at A-kinase anchoring proteins (AKAPs), which are attracted to $\beta$-adrenoceptors [for review see [32]]. In our perforated patch clamp experiments on microglial cells, noradrenergic agonists do not affect the $\mathrm{Cl}^{-}$conductance under isotonic conditions $\left(\mathrm{I}_{C l, \text { basal }}\right)$. However, these agonists 
modulate osmotically-activated $\mathrm{I}_{C l, \text { swell }}$ If the osmotic environmental conditions are crucial for sensitizing immune cells to noradrenergic agonists, the lack of studies reporting adrenergic modulation of $\mathrm{I}_{C l, \text { swell }}$ in immune cells is due to neglecting osmotic gradients across the plasma membrane. The decrease of $\mathrm{I}_{C l, \text { swell }}$ by application of NA or ISOP to osmotically-activated $\mathrm{I}_{C l, \text { swell }}$ is mimicked either by Epac activation by 8-pCPT-2-0-Me-cAMP or by inhibition of PKA by H89. Compared to the first time applications of adrenergic agonists, subsequent applications caused substantially weaker or lacking suppressive responses of $\mathrm{I}_{C l, \text { swell }}$ Similarly, 8-pCPT-2O-Me-cAMP and H89 suppressed $\mathrm{I}_{C l, s w e l l}$ when added for the first time, but were ineffective when added for the second time, indicating a use-dependent desensitization of $\mathrm{I}_{c l, s w e l l}$ Our findings that Epac activation mimics the desensitizing effect of repeated adrenergic activation support the assumption that the desensitization is a consequence of switching intracellular signaling pathways [52] [for review see [53]].

\section{Noradrenaline, $I_{\text {Cl,swell }}$ and phagocytosis in microglia}

The discussion, whether catecholamines suppress or enhance inflammatory processes is controversial [3, 54-58] [for review see [59]]. Cell volume regulatory processes have been considered to contribute to migration and phagocytosis [13, 21-25, 27, 60, 61]. Both processes are relevant in immune responses. Cellular migration contributes to the deployment of macrophages from lymphoid tissue to the site of inflammation and phagocytosis removes pathogenic particles. Enhancement or suppression of $\mathrm{I}_{C l, \text { swell }}$ is a ubiquitous modulatory mechanism of RVD in many cell types [for review see $[17,18,20,62]]$. Blockade of $I_{C l, s w e l l}$ in microglial cells impairs the formation of lamellipodia and engulfment pseudopodia as well as ramifications $[9,13,26]$.

In the present study, we demonstrate that $\mathrm{I}_{C l, \text { swell }}$ is sensitive to cAMP-elevating adrenergic stimulation. In a previous study, we described that the $\beta$-adrenergic agonist ISOP, as well as cAMP-elevating agents, like the adenylyl cyclase activator forskolin and the phosphodiesterase inhibitor 3-isobutyl-1-methylxanthine (IBMX), decrease phagocytosis in microglial cells [5]. This observation is in agreement with reports showing an association between an increase in cAMP and a decrease in phagocytosis in alveolar macrophages [33], in macrophages differentiated in vitro from human peripheral monocytes [34], in the human monoblast cell line (U937) [35] and murine microglia [4, 36]. In contrast to these observations, Heneka and co-workers found that NA stimulates phagocytosis in microglia [3]. The difference between our observation and those from Heneka and co-workers could be related to (1) the time of exposure to cAMP-elevating agents (15 minutes in our study versus four hours), (2) the target of phagocytosis (IgG-labeled microspheres versus fibrillary fluorescent-labeled $A \beta_{1-42}$ ) and (3) the method of quantification (scanning electron microscopy versus FACScan). Previous studies have demonstrated that cAMP-dependent suppression of phagocytosis involves Epac [5] as well as PKA [34, 36]. Because we observed that an Epac-dependent pathway suppresses $\mathrm{I}_{c l, s w e l l}$ (present study) and that $\mathrm{Cl}^{-}$channel blockers impair phagocytosis in microglial cells [13], we suggest that a cAMP-Epac-dependent pathway contributes to a NA- and ISOP-associated suppression of phagocytosis in microglial cells. Because the PKA-blocker H89 suppresses $I_{C l, s w e l l}$ as well as phagocytosis, we suggest that a cAMP-PKA-dependent pathway supports phagocytosis. In the present as well as in a previous study [5], we observed that NA, the $\beta$-adrenergic agonist ISOP, the $\alpha$-adrenergic agonists phenylephrine ( $\alpha 1$-adrenergic agonist) and metaraminol ( $\alpha 1$ - and $\alpha 2$-adrenergic agonist) suppress phagocytosis. Puzzling, the $\beta$-adrenergic antagonist, propranolol, and the $\alpha$-adrenergic antagonists yohimbine ( $\alpha 2$-adrenergic antagonist) and phentolamine $(\alpha 1$ and $\alpha_{2}$-adrenergic antagonist), further enhance NA-induced suppression of phagocytosis (present study). The observations that different messengers evoke different physiological responses using the same second messenger, i.e. cAMP, could be related to the spatial and temporal compartmentalization of the cAMP-response [for review see [31]]. Thus, facilitation as well as suppression of phagocytosis could be related to an increase in cAMP. In a shortterm modulation of phagocytosis, a cAMP-Epac-dependent pathway dominates and impairs phagocytosis, whereas in a long-term modulation a cAMP-PKA-dependent pathway could 


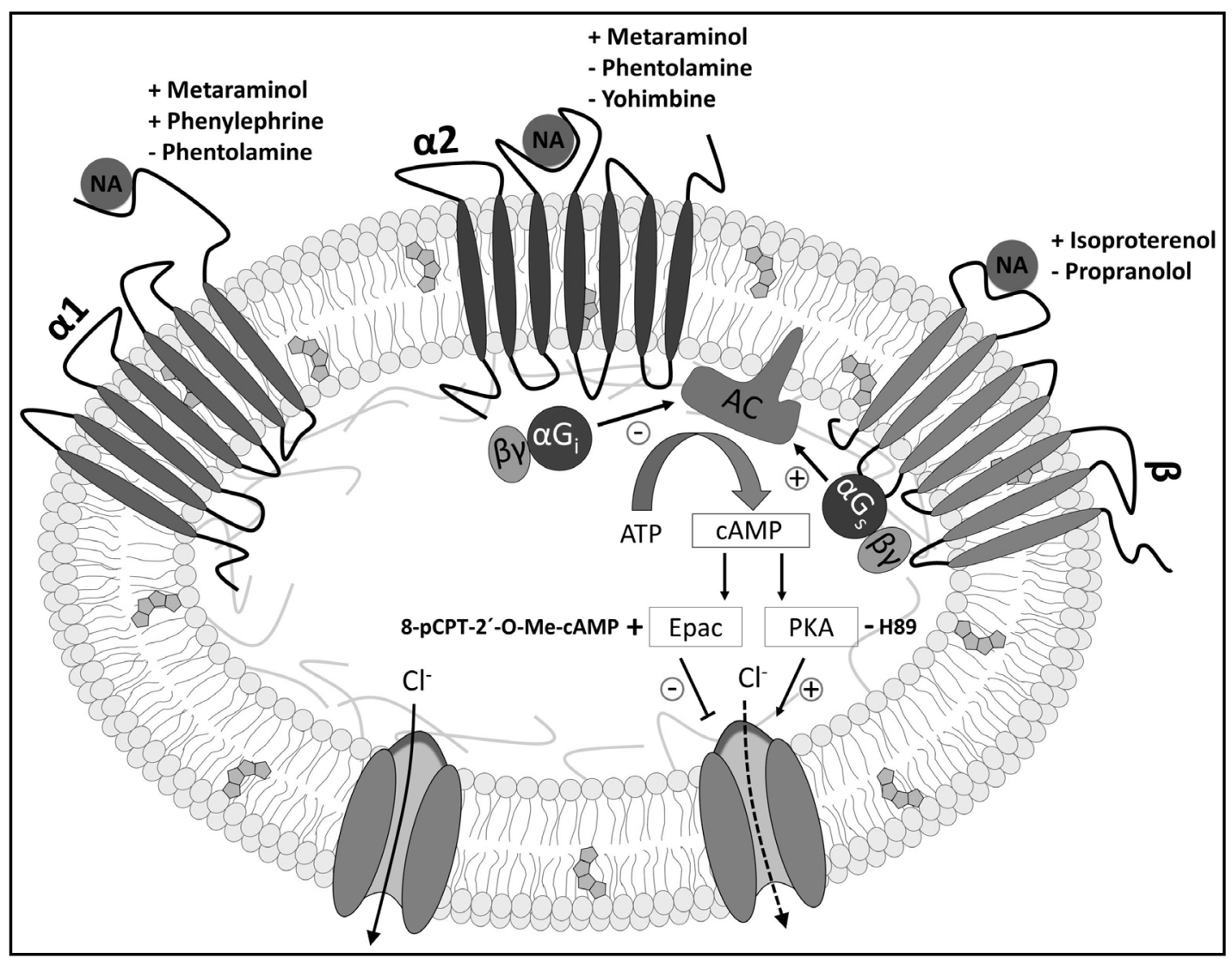

Fig. 9. Noradrenergic suppression of the swelling activated $\mathrm{Cl}^{-}$current $\mathrm{I}_{\mathrm{Cl}, \text { swell }}$. Putative model of suppression of $\mathrm{I}_{\mathrm{Cl} \text {,swell }}$ by norardrenaline and isoproterenol in microglial cells. The activation of $\beta$-adrenergic receptors stimulates a G-protein-adenylate cyclase (AC) system, which catalyses the formation of cAMP. Subsequently, cAMP activates cAMP-binding proteins including PKA and Epac which in turn are involved in the regulation of $\mathrm{I}_{\mathrm{Cl}, \text { swell }}$ by yet unknown mechanisms.

dominate and facilitate phagocytosis. Alternatively, the spatial distribution of $\mathrm{I}_{C l \text { swell }}$ enhancing and suppressing cAMP-dependent factors along the proximal distal axis of a phagocytic cup could coordinate particle engulfment. If both cAMP-dependent pathways are activated simultaneously, the formation of a phagocytic cup is impaired. Accordingly, simultaneous application of $\alpha$ - and $\beta$-adrenergic agonists or antagonists could impair particle uptake by activating overlapping cAMP-dependent pathways simultaneously.

The present findings may explain the controversial observations of NA on physiological properties of immune cells. Depending on the dominance of either a cAMP-Epac- or a cAMPPKA-dependent pathway, opposing observations on migration, phagocytosis or additional immunological functions may be the consequence. In a physiological context, the time course of NA release or of removal of NA from the extracellular environment may affect the immunological response: oscillatory or pulsatile release of NA may favor a cAMP-Epacdependent pathway, whereas a chronic or tonic release may favor a cAMP-PKA-dependent pathway.

\section{Conclusion}

In summary, this study provides strong evidence that the $\beta$-adrenergic stimulation of microglial BV-2 cells triggers a cAMP-Epac-dependent- and cAMP-PKA-dependent cascade which affects phagocytosis via modulation of the swelling-activated $\mathrm{Cl}^{-}$current, $\mathrm{I}_{C l \text { swell }}$ (figure 9). 


\section{Cellular Physiology Cell Physiol Biochem 2019;52:951-969

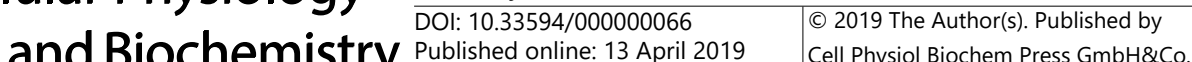 \\ Kittl et al.: Modulation of Microglial I I.Swell $/$ VRAC by Noradrenaline via Epac}

\section{Abbreviations}

AKAP (A-kinase anchoring protein); AC (adenylyl cyclase); cAMP (3'-5'-cyclic adenosine monophosphate); DCPIB ((4-[(2-Butyl-6,7-dichloro-2-cyclopentyl-2,3-dihydro-1-oxo1H-inden-5-yl)oxy]butanoic acid); DMSO (dimethylsulfoxide); Epac (exchange protein activated by cAMP); HMDS (hexamethyldisilazane); MPTP (1-methyl-4-phenyl-1,2,3,6 tetrahydropyridine); Gluc (Gluconate); H89 (N-[2-(p-bromocinnamylamino)ethyl]-5isoquinolinesulfonamide dihydrochloride); IBMX (phosphodiesterase inhibitor 3-isobutyl1-methylxanthine); $\mathrm{I}_{C l \text { swell }}$ (swelling-activated chloride $\left(\mathrm{Cl}^{-}\right)$current); ISOP (Isoproterenol); PDE (phosphodiesterase); NA (noradrenaline); NPPB ((5-Nitro-2-(3-phenylpropylamino) benzoic acid)); PKA (cAMP-dependent protein kinase A); PKC (protein kinase C); RVD (regulatory volume decrease); RVI (regulatory volume increase); VRAC (volume regulated anion current); 8-pCPT-2-0-Me-cAMP (8-(4-Chlorophenylthio)-2'-0-methyladenosine-3',5'cyclic monophosphate; in figure 6 also abbreviated as 8pCPT).

\section{Acknowledgements}

The first author was supported by the Doctoral College "Interdisciplinary Stress Physiology" of the University of Salzburg and by the Forschungsförderungsfonds of the Paracelsus Medical University (PMU-FFF) grant Nr. R-15/05/073-KIT.

\section{Disclosure Statement}

The authors declare that there are no conflicts of interest.

\section{References}

- 1 Adolfsson R, Gottfries CG, Roos BE, Winblad B: Changes in the brain catecholamines in patients with dementia of Alzheimer type. Br J Psychiatry 1979;135:216-223.

2 Heneka MT, Galea E, Gavriluyk V, Dumitrescu-Ozimek L, Daeschner J, O’Banion MK, Weinberg G, Klockgether T, Feinstein DL: Noradrenergic depletion potentiates beta -amyloid-induced cortical inflammation: implications for Alzheimer's disease. J Neurosci 2002;22:2434-2442.

- 3 Heneka MT, Nadrigny F, Regen T, Martinez-Hernandez A, Dumitrescu-Ozimek L, Terwel D, JardanhaziKurutz D, Walter J, Kirchhoff F, Hanisch UK, Kummer MP: Locus ceruleus controls Alzheimer's disease pathology by modulating microglial functions through norepinephrine. Proc Natl Acad Sci U S A 2010;107:6058-6063.

- 4 Makranz C, Cohen G, Reichert F, Kodama T, Rotshenker S: cAMP cascade (PKA, Epac, adenylyl cyclase, $\mathrm{Gi}$, and phosphodiesterases) regulates myelin phagocytosis mediated by complement receptor-3 and scavenger receptor-AI/II in microglia and macrophages. Glia 2006;53:441-448.

- 5 Steininger TS, Stutz H, Kerschbaum HH: Beta-adrenergic stimulation suppresses phagocytosis via Epac activation in murine microglial cells. Brain Res 2011;1407:1-12.

6 Charolidi N, Schilling T, Eder C: Microglial Kv1.3 Channels and P2Y12 Receptors Differentially Regulate Cytokine and Chemokine Release from Brain Slices of Young Adult and Aged Mice. PLoS One 2015;10:e0128463.

- 7 Grossinger EM, Weiss L, Zierler S, Rebhandl S, Krenn PW, Hinterseer E, Schmolzer J, Asslaber D, Hainzl S, Neureiter D, Egle A, Pinon-Hofbauer J, Hartmann TN, Greil R, Kerschbaum HH: Targeting proliferation of chronic lymphocytic leukemia (CLL) cells through KCa3.1 blockade. Leukemia 2014;28:954-958.

- 8 Arumugham VB, Baldari CT: cAMP: a multifaceted modulator of immune synapse assembly and T cell activation. J Leukoc Biol 2017;101:1301-1316.

- 9 Eder C: Ion channels in microglia (brain macrophages). Am J Physiol 1998;275:C327-342. 


\section{Cellular Physiology Cell Physiol Biochem 2019;52:951-969 \begin{tabular}{c|c|c|} 
DOl: $10.33594 / 000000066$ & O 2019 The Author(s). Published by \\
and Biochemistry & Published online: 13 April 2019 & Cell $P h y s$
\end{tabular}

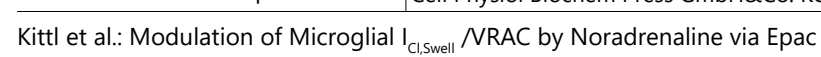

- 10 Cahalan MD, Chandy KG: The functional network of ion channels in T lymphocytes. Immunol Rev 2009;231:59-87.

- 11 Eder C: Ion channels in monocytes and microglia/brain macrophages: promising therapeutic targets for neurological diseases. J Neuroimmunol 2010;224:51-55.

- 12 Furtner T, Zierler S, Kerschbaum HH: Blockade of chloride channels suppresses engulfment of microspheres in the microglial cell line, BV-2. Brain Res 2007;1184:1-9.

- 13 Harl B, Schmolzer J, Jakab M, Ritter M, Kerschbaum HH: Chloride channel blockers suppress formation of engulfment pseudopodia in microglial cells. Cell Physiol Biochem 2013;31:319-337.

- 14 Komm B, Beyreis M, Kittl M, Jakab M, Ritter M, Kerschbaum HH: Glycine modulates membrane potential, cell volume, and phagocytosis in murine microglia. Amino Acids 2014;46:1907-1917.

- 15 Lewis RS, Ross PE, Cahalan MD: Chloride channels activated by osmotic stress in T lymphocytes. J Gen Physiol 1993;101:801-826.

- 16 Cahalan MD, Lewis RS: Functional roles of ion channels in lymphocytes. Semin Immunol 1990;2:107-117.

- 17 Hoffmann EK: Ion channels involved in cell volume regulation: effects on migration, proliferation, and programmed cell death in non adherent EAT cells and adherent ELA cells. Cell Physiol Biochem 2011;28:1061-1078.

- 18 Jakab M, Furst J, Gschwentner M, Botta G, Garavaglia ML, Bazzini C, Rodighiero S, Meyer G, Eichmueller S, Woll E, Chwatal S, Ritter M, Paulmichl M: Mechanisms sensing and modulating signals arising from cell swelling. Cell Physiol Biochem 2002;12:235-258.

19 Lang F, Hoffmann EK: Role of ion transport in control of apoptotic cell death. Compr Physiol 2012;2:20372061.

- 20 Lang F, Busch GL, Ritter M, Volkl H, Waldegger S, Gulbins E, Haussinger D: Functional significance of cell volume regulatory mechanisms. Physiol Rev 1998;78:247-306.

- 21 Jakab M, Ritter M: Cell volume regulatory ion transport in the regulation of cell migration. Contrib Nephrol 2006;152:161-180.

22 Schwab A: Ion channels and transporters on the move. News Physiol Sci 2001;16:29-33.

- 23 Schwab A, Nechyporuk-Zloy V, Fabian A, Stock C: Cells move when ions and water flow. Pflugers Arch 2007;453:421-432.

24 Schwab A, Stock C: Ion channels and transporters in tumour cell migration and invasion. Philos Trans R Soc Lond B Biol Sci 2014;369:20130102.

25 Stock C, Ludwig FT, Hanley PJ, Schwab A: Roles of ion transport in control of cell motility. Compr Physiol 2013;3:59-119.

26 Zierler S, Frei E, Grissmer S, Kerschbaum HH: Chloride influx provokes lamellipodium formation in microglial cells. Cell Physiol Biochem 2008;21:55-62.

27 Schwab A, Fabian A, Hanley PJ, Stock C: Role of ion channels and transporters in cell migration. Physiol Rev 2012;92:1865-1913.

- 28 Pappalardo LW, Black JA, Waxman SG: Sodium channels in astroglia and microglia. Glia 2016;64:16281645.

29 Ahles A, Engelhardt S: Polymorphic variants of adrenoceptors: pharmacology, physiology, and role in disease. Pharmacol Rev 2014;66:598-637.

30 Cheng X, Ji Z, Tsalkova T, Mei F: Epac and PKA: a tale of two intracellular cAMP receptors. Acta Biochim Biophys Sin (Shanghai) 2008;40:651-662.

31 Robichaux WG, 3rd, Cheng X: Intracellular cAMP Sensor EPAC: Physiology, Pathophysiology, and Therapeutics Development. Physiol Rev 2018;98:919-1053.

32 Giembycz MA, Newton R: Beyond the dogma: novel beta2-adrenoceptor signalling in the airways. Eur Respir J 2006;27:1286-1306.

33 Aronoff DM, Canetti C, Peters-Golden M: Prostaglandin E2 inhibits alveolar macrophage phagocytosis through an E-prostanoid 2 receptor-mediated increase in intracellular cyclic AMP. J Immunol 2004;173:559-565.

34 Bryn T, Mahic M, Enserink JM, Schwede F, Aandahl EM, Tasken K: The cyclic AMP-Epac1-Rap1 pathway is dissociated from regulation of effector functions in monocytes but acquires immunoregulatory function in mature macrophages. J Immunol 2006;176:7361-7370. 


\section{Cellular Physiology Cell Physiol Biochem 2019;52:951-969 \begin{tabular}{c|c|c|c|c|}
\hline DOl: 10.33594/000000066 & O 2019 The Author(s). Published by \\
\hline and Biochemistry
\end{tabular} and Biochemistry Published online: 13 April 2019 Cell Physiol Biochem Press GmbH\&Co. KG \\ Kittl et al.: Modulation of Microglial $\mathrm{I}_{\mathrm{Cl}, \text { swell }} /$ VRAC by Noradrenaline via Epac}

- 35 Nambu M, Morita M, Watanabe H, Uenoyama Y, Kim KM, Tanaka M, Iwai Y, Kimata H, Mayumi M, Mikawa H: Regulation of Fc gamma receptor expression and phagocytosis of a human monoblast cell line U937. Participation of cAMP and protein kinase $\mathrm{C}$ in the effects of IFN-gamma and phorbol ester. J Immunol 1989;143:4158-4165.

- 36 Schmidt C, Schneble N, Muller JP, Bauer R, Perino A, Marone R, Rybalkin SD, Wymann MP, Hirsch E, Wetzker R: Phosphoinositide 3-kinase gamma mediates microglial phagocytosis via lipid kinase-independent control of cAMP. Neuroscience 2013;233:44-53.

- 37 Svoboda N, Pruetting S, Grissmer S, Kerschbaum HH: cAMP-dependent chloride conductance evokes ammonia-induced blebbing in the microglial cell line, BV-2. Cell Physiol Biochem 2009;24:53-64.

38 Holz GG, Kang G, Harbeck M, Roe MW, Chepurny OG: Cell physiology of cAMP sensor Epac. J Physiol 2006;577:5-15.

39 Klein B, Worndl K, Lutz-Meindl U, Kerschbaum HH: Perturbation of intracellular $\mathrm{K}^{+}$homeostasis with valinomycin promotes cell death by mitochondrial swelling and autophagic processes. Apoptosis 2011;16:1101-1117.

40 Lehnardt S, Henneke P, Lien E, Kasper DL, Volpe JJ, Bechmann I, Nitsch R, Weber JR, Golenbock DT, Vartanian T: A mechanism for neurodegeneration induced by group B streptococci through activation of the TLR2/MyD88 pathway in microglia. J Immunol 2006;177:583-592.

- 41 Blasi E, Barluzzi R, Bocchini V, Mazzolla R, Bistoni F: Immortalization of murine microglial cells by a v-raf/ v-myc carrying retrovirus. J Neuroimmunol 1990;27:229-237.

- 42 Voets T, Droogmans G, Nilius B: Modulation of voltage-dependent properties of a swelling-activated Clcurrent. J Gen Physiol 1997;110:313-325.

- 43 Eder C, Klee R, Heinemann U: Involvement of stretch-activated Cl- channels in ramification of murine microglia. J Neurosci 1998;18:7127-7137.

- 44 Schlichter LC, Mertens T, Liu B: Swelling activated Cl- channels in microglia: Biophysics, pharmacology and role in glutamate release. Channels (Austin) 2011;5:128-137.

45 Ross PE, Garber SS, Cahalan MD: Membrane chloride conductance and capacitance in Jurkat Tymphocytes during osmotic swelling. Biophys J 1994;66:169-178.

46 Watson PA, Giger KE, Frankenfield CM: Activation of adenylate cyclase during swelling of S49 cells in hypotonic medium is not involved in subsequent volume regulation. Mol Cell Biochem 1991;104:51-56.

47 Weiss H, Lang F: Ion channels activated by swelling of Madin Darby canine kidney (MDCK) cells. J Membr Biol 1992;126:109-114.

48 Maldonado D, Schumann M, Nghiem P, Dong Y, Gardner P: Prostaglandin E1 activates a chloride current in Jurkat T lymphocytes via cAMP-dependent protein kinase. FASEB J 1991;5:2965-2970.

- 49 Aromataris EC, Roberts ML, Barritt GJ, Rychkov GY: Glucagon activates Ca2+ and Cl- channels in rat hepatocytes. J Physiol 2006;573:611-625.

- 50 Xiao GS, Zhang YH, Wang Y, Sun HY, Baumgarten CM, Li GR: Noradrenaline up-regulates volume-regulated chloride current by PKA-independent cAMP/exchange protein activated by cAMP pathway in human atrial myocytes. Br J Pharmacol 2018; DOI:10.1111/bph.14392.

- 51 Lohse MJ: The ins and outs of adrenergic signaling. J Mol Med (Berl) 2015;93:955-962.

- 52 Castillo-Badillo JA, Sanchez-Reyes OB, Alfonzo-Mendez MA, Romero-Avila MT, Reyes-Cruz G, Garcia-Sainz JA: alpha1B-adrenergic receptors differentially associate with Rab proteins during homologous and heterologous desensitization. PLoS One 2015;10:e0121165.

53 Lefkowitz RJ: Historical review: a brief history and personal retrospective of seven-transmembrane receptors. Trends Pharmacol Sci 2004;25:413-422.

54 Harle P, Mobius D, Carr DJ, Scholmerich J, Straub RH: An opposing time-dependent immune-modulating effect of the sympathetic nervous system conferred by altering the cytokine profile in the local lymph nodes and spleen of mice with type II collagen-induced arthritis. Arthritis Rheum 2005;52:1305-1313.

55 O’Sullivan JB, Ryan KM, Curtin NM, Harkin A, Connor TJ: Noradrenaline reuptake inhibitors limit neuroinflammation in rat cortex following a systemic inflammatory challenge: implications for depression and neurodegeneration. Int J Neuropsychopharmacol 2009;12:687-699.

- 56 McNamee EN, Griffin EW, Ryan KM, Ryan KJ, Heffernan S, Harkin A, Connor TJ: Noradrenaline acting at beta-adrenoceptors induces expression of IL-1beta and its negative regulators IL-1ra and IL-1RII, and drives an overall anti-inflammatory phenotype in rat cortex. Neuropharmacology 2010;59:37-48. 


\section{Cellular Physiology Cell Physiol Biochem 2019;52:951-969

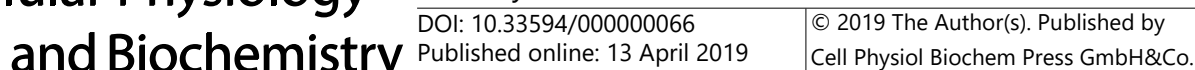 \\ Kittl et al.: Modulation of Microglial I I, ${ }_{\text {Swell }}$ NRAC by Noradrenaline via Epac}

57 McNamee EN, Ryan KM, Griffin EW, Gonzalez-Reyes RE, Ryan KJ, Harkin A, Connor TJ: Noradrenaline acting at central beta-adrenoceptors induces interleukin-10 and suppressor of cytokine signaling-3 expression in rat brain: implications for neurodegeneration. Brain Behav Immun 2010;24:660-671.

- 58 Straub RH, Rauch L, Rauh L, Pongratz G: Sympathetic inhibition of IL-6, IFN-gamma, and KC/CXCL1 and sympathetic stimulation of TGF-beta in spleen of early arthritic mice. Brain Behav Immun 2011;25:17081715.

59 Scanzano A, Schembri L, Rasini E, Luini A, Dallatorre J, Legnaro M, Bombelli R, Congiu T, Cosentino M, Marino F: Adrenergic modulation of migration, CD11b and CD18 expression, ROS and interleukin-8 production by human polymorphonuclear leukocytes. Inflamm Res 2015;64:127-135.

60 Warskulat U, Zhang F, Haussinger D: Modulation of phagocytosis by anisoosmolarity and betaine in rat liver macrophages (Kupffer cells) and RAW 264.7 mouse macrophages. FEBS Lett 1996;391:287-292.

61 Ritter M, Schratzberger P, Rossmann H, Woll E, Seiler K, Seidler U, Reinisch N, Kahler CM, Zwierzina H, Lang HJ, Lang F, Paulmichl M, Wiedermann CJ: Effect of inhibitors of $\mathrm{Na}+\mathrm{H}+$-exchange and gastric $\mathrm{H}+$ / $\mathrm{K}+$ ATPase on cell volume, intracellular $\mathrm{pH}$ and migration of human polymorphonuclear leucocytes. $\mathrm{Br} \mathrm{J}$ Pharmacol 1998;124:627-638.

62 Jentsch TJ: VRACs and other ion channels and transporters in the regulation of cell volume and beyond. Nat Rev Mol Cell Biol 2016;17:293-307. 